\title{
PLANEJAMENTO, ORÇAMENTO E PLURIANUALIDADE
}

A organização do sistema jurídico que regula a atividade financeira do Estado exige periodicidade. Há que se estabelecer prazos para as leis orçamentárias, a fim de que seja possível determinar nelas os atos de arrecadação, gestão, gasto de recursos e demais relacionados com a atividade financeira, permitindo também o respectivo controle.

$\mathrm{O}$ ato de planejar envolve sempre, e necessariamente, a previsão sobre o futuro. Antecipar fatos, situações e, a partir de então, estabelecer a forma de condução com vistas a atingir determinados objetivos em face desse cenário desenhado.

$\mathrm{O}$ que se revela, adiante-se, talvez um dos principais problemas que afetam o ato de planejar e transformá-lo em normas, tornando necessário que proporcionem segurança jurídica, de modo que possam orientar não só a ação do Estado, como também de todos aqueles com os quais se relaciona.

E a ideia de previsão também supõe a periodicidade, conforme assevera José Afonso da Silva: "A programação orçamentária, como a planificação econômica e social de que é a etapa operativa, rege-se pela regra da previsão", que "supõe a de periodicidade, que se baseia, por seu lado, na caracterização dinâmica da ação estatal que se há de orientar no sentido da consecução do máximo nível dinâmico do bem- estar para a comunidade e, como as necessidades variam constantemente, deverá o Estado rever periodicamente sua programação para ajustá-la às circunstâncias cambiantes, à inexorável dinâmica da realidade social”. E segue mostrando que:

"a periodicidade orçamentária interessa do ponto de vista político, financeiro e econômico. (...) Seu interêsse do ponto-de-vista financeiro está em marcar-se um período 
durante o qual se efetue a arrecadação e contabilização dos ingressos e se comprometam e paguem as despesas autorizadas, de maneira que se garantam a ordem e a adequada formação e execução orçamentária, encerrando-se as contas públicas em determinado momento e procedendo-se os respectivos balanços e contrôles de resultados".

Entre as importantes questôes que se colocam, está a do horizonte temporal do planejamento. Qual é o prazo desejado e adequado para planejar?

Trata-se, vê-se desde logo, de questão cuja resposta é não somente complexa, como também evidentemente variável, sujeita a uma série de fatores, e seguramente importará em múltiplas possibilidades, dada a variedade de situações a que se aplica.

Admite-se, no âmbito do setor público, que se pode compreender o horizonte temporal do planejamento nas categorias de curto, médio e longo prazos.

Considera-se planejamento de curto prazo aquele que contempla períodos de até um ano, sendo as leis orçamentárias o instrumento por excelência de veiculação desse planejamento orçamentário.

Daí falar-se em anualidade orçamentária, erigida pela doutrina à condição de princípio de Direito Orçamentário - o princípio da anualidade orçamentária -, que, no entanto, como se verá, tem sido questionado, exigindo atualmente melhor reflexão sobre seu significado e extensão, e até mesmo sobre sua aplicação, o que justifica uma análise mais aprofundada, o que será feito no item 3.1 infra.

Não obstante o período anual também comportar a atividade planejadora, a plurianualidade é inerente à função de planejamento. ${ }^{2}$

José Afonso da Silva evidencia que, do ponto de vista econômico, o período mais conveniente é o cíclico, que permite acomodar as flutuações depressivas e expansivas da economia; porém, tendo em vista que, sob o aspecto contábil, há maior conveniência, firmou-se a periodicidade anual. ${ }^{3}$

Dada a necessidade de compatibilização com o sistema de planejamento, o jurista mostra que o sistema orçamentário brasileiro, que integra orçamento e

SILVA, José Afonso da. Orçamento-programa no Brasil, p. 132-133.

2 Nesse sentido, interessante destacar trecho da decisão da Corte Constitucional da Colômbia, que, ao se manifestar sobre o tema, reconhece ser da natureza do plano de investimentos públicos, previsto no art. 339 da Constituição colombiana, estabelecer orçamentos plurianuais, por ser impossível planejar um desenvolvimento harmônico e integral com base na anualidade absoluta, uma vez que o desenvolvimento sugere previsão de metas de longo prazo. "Sin la plurianualidad, el proceso presupuestal no estaría en harmonía con el proceso de planeación, lo cual contraviene el espíritu de la Carta”, finaliza a decisão (Sentença C-337, de 19 de agosto de 1993, citada por RESTREPO, Juan Camilo. Hacienda pública, p. 342).

3 SILVA, José Afonso da. Orçamento-programa no Brasil, p. 133-134. 
planejamento, "concilia ambas as exigências, ou seja, o princípio da anualidade e o princípio da plurianualidade cíclica". ${ }^{4}$

Admite-se, portanto, em matéria orçamentária, também o princípio da plurianualidade, que é inerente à ideia de planejamento, atividade para a qual o período anual mostra-se incompatível, inadequado e insuficiente para atender às necessidades de organização da atividade financeira do Estado, especialmente considerando as cada vez maiores e fundamentais obras de infraestrutura que se fazem necessárias, bem como os contratos com o poder público, em regra estabelecidos para prazos superiores a um ano.

Atualmente, a cada vez mais presente e necessária integração entre planejamento e orçamento, que se materializa no sistema de planejamento orçamentário da administração pública, exige uma adequada interpretação dos conceitos de anualidade e plurianualidade, a fim de compatibilizá-los de modo que possam harmonizar-se em torno de um ordenamento jurídico coeso.

Rodrigo Faria propõe a adequação da interpretação do princípio da anualidade, que deve ser lido de forma conjunta com o da plurianualidade orçamentária, concluindo que

"há que se proceder à sua compatibilização (do princípio da anualidade orçamentária) com os demais princípios integrantes da Carta de 1988, sob pena da invalidação de outros princípios que lhe são correlatos. Alegações genéricas de violação ao princípio da anualidade são destituídas de significado, quando há outros princípios que informam regras que, no caso concreto, diminuem o alcance do princípio da anualidade. Ou seja, os princípios podem sofrer limitação de sua incidência, em face de outros princípios de sentido oposto, porque não existem princípios absolutos nos ordenamentos jurídicos. Com a anualidade orçamentária não poderia ser diferente".

Exemplifica com o caso dos investimentos de natureza plurianual, em que se deve sopesar o princípio da anualidade com o da plurianualidade (CF, art.

\footnotetext{
SILVA, José Afonso da. Orçamento-programa no Brasil, p. 134.

Como já mencionado, em texto de minha autoria, "Essas despesas (referindo-nos aos gastos plurianuais) hoje são fundamentais para assegurar o desenvolvimento econômico e social, especialmente em função das grandes obras de infraestrutura, cada vez mais necessárias para melhorar o bem-estar de nossa sociedade. Basta ver as imprescindíveis obras voltadas a favorecer a mobilidade urbana, problema crescente nas grandes metrópoles, que exigem altos investimentos em transportes coletivos de massa, como o metroviário, vias rápidas e outros; ou ainda as grandes obras voltadas à produção de energia, como usinas hidrelétricas. Todas obras de grande vulto, fundamentais para o país, e cuja implantação ultrapassa em muito o período do exercício financeiro" (CONTI, José Mauricio. O final de ano, as dívidas e os "restos a pagar". Levando o direito financeiro a sério, p. 217).
} 
167, $\$ 1^{\circ}$ ), eficiência $(\mathrm{CF}$, art. 37, caput), continuidade e economicidade, para reconhecer que deve prevalecer na hipótese o tratamento plurianual dos referidos investimentos. ${ }^{6}$

O grande desafio, como se está analisando ao longo deste trabalho, é, nas palavras de Cabral de Moncada, "estabelecer as correias de transmissão entre o plano e o orçamento", por meio de regras e técnicas orçamentárias e financeiras, que, em última análise, tendem a compatibilizar e dar coerência à anualidade e plurianualidade orçamentárias. ${ }^{7}$

Alguns países estabelecem essas ligações organizando o sistema de planejamento com uma separação em documentos diferentes, criando o "orçamento de capital" (capital budget) para as despesas de investimento, usualmente de prazo mais longo, e o "orçamento corrente" (budget for current expenditures), mais facilmente materializáveis em termos financeiros. A Organização para a Cooperação e Desenvolvimento Econômico (OCDE) registra que 61\% de seus membros realizam esse tipo de separação. ${ }^{8}$

A evolução da anualidade orçamentária, passando para um sistema que admite e reconhece a plurianualidade como um conceito mais adequado às modernas técnicas de gestão e planejamento, é bem evidenciada no direito francês, como se vê com clareza nos textos do professor Michel Bouvier, valendo abrir espaço nesse momento para uma síntese de suas exposições, que permitem uma análise mais detalhada de um aperfeiçoamento que se mostrou presente em vários países.

Ao tratar da questão do planejamento de médio prazo na França, o professor Michel Bouvier relembra frase escrita em 1976 por Renaud de la Genière: "A programação plurianual constitui a síntese mais avançada das concepções orçamentárias modernas". Segundo o jurista francês, apesar desse reconhecimento da importância da programação plurianual, compartilhado há muito tempo pelos

6 FARIA, Rodrigo Oliveira de. Reflexão sobre o conflito entre princípios orçamentários. Interesse público, p. 100-102.

7 "O problema essencial que se levanta nessa matéria é o de estabelecer as correias de transmissão entre o plano e o orçamento, atendendo a que o primeiro vigora normalmente para um período de vários anos, ao passo que o segundo está limitado pela regra da anualidade (art. $2^{\circ} \mathrm{da}$ cit. Lei n. 64/77). O resultado é que é forçoso temperar esta regra, sob a influência das exigências do plano, o que se traduz no surto de novas técnicas orçamentais e financeiras, além de impor determinados métodos de avaliação e classificação das despesas orçamentais segundo novos princípios de racionalidade financeira, tão próxima da racionalidade dos agentes econômicos privados" (MONCADA, Luís S. Cabral de. A problemática jurídica do planeamento económico, p. 102-103).

8 OECD. Budgeting practices and procedures in OECD countries, p. 44. 
especialistas em finanças públicas, a implantação de um dispositivo eficaz nunca ocorreu de maneira definitiva, mas "tem sido admitido que programar permite aos gestores disporem do tempo necessário para executar uma política e de uma duração e de uma visibilidade que lhes são indispensáveis para agirem e se sentirem responsáveis".

A anualidade restringe a ação administrativa ao curto prazo e impede que sejam medidos os impactos das decisões orçamentárias a longo prazo; no entanto, o princípio da anualidade tem feito parte dos dogmas orçamentários por razões de natureza política, eis que, historicamente, as exigências do regime representativo impuseram uma periodicidade breve, que garantisse a eficácia do controle parlamentar sobre as finanças públicas. ${ }^{10}$

$\mathrm{Na}$ França, as primeiras tentativas de ultrapassar o enquadramento anual do orçamento ocorreram durante a Terceira República, sob a forma de "orçamentos reconduzidos ou bianuais". Os "orçamentos reconduzidos" consistiam na utilização do orçamento do exercício anterior, ao passo que os orçamentos bianuais, na fixação em uma só vez, por um único voto, das receitas e despesas para dois exercícios consecutivos. A última proposta nesse sentido foi apresentada em 1934 pelo Governo Doumergue. Porém, como ressaltam Bouvier, Esclassan e Lassale, tratava-se de uma simples facilidade política, para economizar uma votação orçamentária, sem que houvesse uma racionalidade econômica que a sustentasse. ${ }^{11}$

Foi no período que sucedeu a Segunda Guerra Mundial, marcado pela ampliação do papel do Estado, que se reviu o princípio da anualidade, por duas razões: a) razões puramente técnicas, ligadas ao desenvolvimento dos investimentos do Estado e à necessidade de maior tempo para conclusão de certas obras; e b) razões econômico-políticas: a programação a médio e longo prazo passa a ser uma das novas ideias da economia contemporânea e os Estados começam a criar instituições novas, com o objetivo de limitar a influência das incertezas na economia. ${ }^{12}$

9 BOUVIER, Michel. Programmation pluriannuelle et équilibre des finances publiques: les conditions du succès, p. 1 e, também, BOUVIER, Michel; ESCLASSAN, Marie-Christine; LASSALE, Jean-Pierre. Finances publiques, p. 289. (Tradução livre.)

10 BOUVIER, Michel. Programmation pluriannuelle et équilibre des finances publiques: les conditions du succès, p. 1 e, também, BOUVIER, Michel; ESCLASSAN, Marie-Christine; LASSALE, Jean-Pierre. Finances publiques, p. 284. (Tradução livre.)

11 BOUVIER, Michel. Programmation pluriannuelle et équilibre des finances publiques: les conditions du succès, p. 1 e, também, BOUVIER, Michel; ESCLASSAN, Marie-Christine; LASSALE, Jean-Pierre. Finances publiques, p. 284-285. (Tradução livre.)

12 BOUVIER, Michel. Programmation pluriannuelle et équilibre des finances publiques: les conditions du succès, p. 1. (Tradução livre.) 
Nesse contexto, o direito orçamentário francês buscou equilibrar dois conceitos contraditórios: o princípio da anualidade; e a necessidade de um planejamento plurianual. A ordenança de 1959, que disciplinava as finanças públicas, previu certos mecanismos de plurianualidade, mas manteve a predominância do princípio da anualidade. Porém, com o tempo, o princípio sofreu profundos questionamentos, por razões externas e internas: os mecanismos de plurianualidade previstos na ordenança de 1959 se mostraram ineficazes ou até mesmo desviaram-se do sentido original; e a influência europeia, com as exigências do Tratado de Estabilidade e Crescimento - que instituiu a moeda única e determinou que os Estados-membros elaborassem programas plurianuais de finanças públicas -, impôs a adoção de uma sistemática plurianual. ${ }^{13}$

Sendo assim, a necessidade de atingir o equilíbrio das contas públicas foi essencial para a implementação concreta da programação a médio termo das finanças públicas. A Lei Orgânica sobre as Leis de Finanças (LOLF), de 2001, substituiu a ordenança de 1959, trazendo importantes inovações às finanças públicas. No tocante à programação plurianual, embora tenha atenuado o princípio de anualidade, "ela não chegou a propor os instrumentos de uma pilotagem plurianual ampla”. ${ }^{14}$ Foi apenas por meio da Revisão Geral de Políticas Públicas e da Revisão Constitucional, ambas de 2008, que foram instituídos mecanismos de programação financeira a médio prazo.

Em síntese, coloca o professor Michel Bouvier,

"é a favor do desenvolvimento de uma cultura da performance que a questão da plurianualidade foi reconsiderada nesses últimos anos. A conjugação dos imperativos financeiros, principalmente ligados a um endividamento mais que excessivo, bem como as exigências europeias, e as reflexões sobre o controle das finanças públicas finalmente puderam se completar em 2008 com a criação de dois dispositivos que não colocam em xeque o princípio da anualidade e que deixam esperar um saneamento das finanças públicas nos próximos anos". 15

A programação plurianual foi oficialmente anunciada pelo Presidente da República em 2007, que declarou durante o primeiro Conselho de modernização das políticas públicas: "nós implementaremos para 2009-2011 um orçamento plurianual coerente com a nossa trajetória de finanças públicas. Trata-se de uma revolução em

13 BOUVIER, Michel. Programmation pluriannuelle et équilibre des finances publiques: les conditions du succès, p. 2. (Tradução livre.)

14 BOUVIER, Michel. Programmation pluriannuelle et équilibre des finances publiques: les conditions du succès, p. 2. (Tradução livre.)

15 BOUVIER, Michel. Programmation pluriannuelle et équilibre des finances publiques: les conditions du succès, p. 2. (Tradução livre.) 
nosso funcionamento administrativo". ${ }^{16}$ Nesse contexto, o dispositivo de programação plurianual foi implementado pela primeira vez na elaboração do orçamento de 2009, com uma duração de três anos.

A revisão constitucional de 23 de julho de 2008 introduziu no ordenamento jurídico francês o conceito de leis de programação plurianual das finanças públicas. Segundo o art. 34 da Constituição modificado, "as orientaçóes plurianuais das finanças públicas são definidas pelas leis de programação. Elas se inscrevem no objetivo de equilíbrio das contas das administraçôes públicas". ${ }^{17}$

As leis de programação, cujo conteúdo é determinado pela Lei Orgânica de 17 de dezembro de 2012, são examinadas pelo Parlamento de acordo com o procedimento legislativo ordinário. A primeira lei de programação foi adotada em 9 de fevereiro de 2009 e correspondia ao período de 2009 a 2012; já a segunda data de 31 de dezembro de 2012, cobrindo o período de 2011 a $2014 .^{18}$

A lei de programação em vigor, terceira lei de programação aprovada, diz respeito ao período de 2012 a 2017 (Lei n. 2.012-1.558, de 31 de dezembro de 2012). Conforme se verifica nesse período, as leis de programação cobrem um período de no mínimo três anos, mas o legislador pode votá-las por um período mais longo. Da mesma forma, é possível adotar uma nova lei de programação antes do fim do período coberto pela lei de programação anterior, como foi o caso da última lei de programação, que corresponde ao período de 2012 a 2017, sem ter esperado o ano de $2014 .{ }^{19}$

A lei de programação 2012-2017 se subdivide em três partes: a primeira traz a programação propriamente dita, propondo a adoção de um relatório anexo, e contém disposições relativas aos objetivos gerais das finanças públicas, principalmente em termos de resultados estruturais ou efetivos, à evolução das despesas no período de 2012 a 2017, à evolução das receitas públicas etc.; a segunda e a terceira partes comportam disposições permanentes relativas à gestão das finanças públicas, assim como à informação e ao controle do parlamento sobre essa gestão. ${ }^{20}$

16 BOUVIER, Michel. Programmation pluriannuelle et équilibre des finances publiques: les conditions du succès, p. 2. (Tradução livre.)

17 BOUVIER, Michel. Programmation pluriannuelle et équilibre des finances publiques: les conditions du succès, p. 3. (Tradução livre.)

18 Governo francês. Programmation pluriannuelle des finances publiques et budget trienal de l'État (2013). Performance Publique.

19 Governo francês. Programmation pluriannuelle des finances publiques et budget trienal de l'État (2013). Performance Publique.

20 Assembleia Nacional francesa. Fiche de synthèse n. 40: L'examen parlementaire des lois de finances (2014). Assemblée Nationale. 
Em seu relatório sobre a situação e as perspectivas das finanças públicas, a Corte de Contas francesa realizou uma avaliação da lei de programação 2014, na qual destaca a importância do instrumento de programação plurianual, "indispensável para posicionar a ação das administrações públicas em uma perspectiva de correção das contas públicas a médio prazo conforme as obrigações contraídas”, e, segundo a Corte, "uma reflexão deve ser rapidamente iniciada sobre as reformas a realizar para reforçar a eficácia desse instrumento". ${ }^{21}$

De todo o exposto, há de se reconhecer que o planejamento se materializa em prazos variáveis, que podemos simplificar nas já mencionadas categorias do curto, médio e longo prazos, reconhecendo a anualidade como período em que se pode admitir um planejamento de curto prazo. E há uma pluralidade de mecanismos de relacionar as normas de planejamento de forma a dar coerência a um sistema que exige diferentes prazos entre elas.

O planejamento de médio prazo usualmente considera períodos entre três e cinco anos. ${ }^{22}$

Planejamentos de longo prazo aplicam-se a períodos superiores a esse, em geral dez anos, não havendo limites máximos, encontrando-se exemplos de vinte, trinta, setenta anos. No Brasil, o Plano Nacional de Educação é previsto para o período de dez anos (CF, art. 214), o mesmo ocorrendo com o Plano Nacional de Cultura (CF, art. 215, $\$ 3^{\circ}$, e Lei n. 12.343/2010), o Plano Nacional da Juventude (CF, art. $\left.227, \$ 8^{\circ}, \mathrm{II}\right)$, havendo outros planos de prazos mais longos, como o Plano Nacional de Mineração 2010-2030, o Plano Estratégico de Desenvolvimento do Centro-Oeste 2007-2020, o Plano Mineiro de Desenvolvimento Integrado (PMDI) de Minas Gerais para o período de 2007-2023, e muitos outros. Planejamentos de longo prazo não comportam a modalidade orçamentária, sendo pouco confiáveis instrumentos que venham a fazer previsóes por prazos iguais ou superiores a dez anos que sejam capazes de detalhar objetivos, metas, prazos e, especialmente, os recursos a serem alocados, uma vez que a atual dinâmica econômica e social não permite construir cenários seguros em todos esses aspectos. Os planejamentos de longo prazo aplicam-se à modalidade do que denominamos planejamento econômico governamental, com diretrizes de caráter mais amplo e estratégico, indicativos, sinalizando os rumos do Estado e balizando a ação governamental.

21 Corte de Contas. La situation et les perspectives des finances publiques (2015), p. 187.

22 Nazaré Cabral fala em médio prazo para os períodos entre três e cinco anos; longo prazo para dez anos; e longuíssimo prazo os períodos compreendidos entre trinta e cinquenta anos (Programação e decisão orçamental. Da racionalidade das decisóes orçamentais à racionalidade econômica, p. 600). 
Várias consideraçôes acerca da plurianualidade e de sua compatibilização com o sistema de planejamento orçamentário exigem tratamento específico, que serão feitas nos itens a seguir.

\subsection{PRINCÍPIO DA ANUALIDADE | MITIGAÇÕES: OS RESTOS A PAGAR, AS DOTAÇÕES PLURIANUAIS E O CARRY-OVER}

O princípio da anualidade traduz a ideia de periodicidade anual da lei orçamentária - alguns autores inclusive preferem falar em princípio da periodicidade.

A periodicidade orçamentária é necessária, tendo em vista que os orçamentos públicos exercem as funçôes de controle, gestão e planejamento, para o que se faz imprescindível estabelecer um período determinado, no qual sejam previstas e autorizadas as receitas e despesas, a fim de que possam ser controladas, permitindo a participação do Poder Legislativo nesse processo, bem como o acompanhamento e a revisão pelo poder público, tendo em mente o dinamismo das relaçôes sociais e econômicas, ${ }^{23}$ e considera-se o período anual ideal para essa renovação da lei orçamentária. Michel Bouvier caminha no mesmo sentido, destacando as razóes políticas que justificam a periodicidade anual do orçamento, em decorrência das exigências do regime representativo, para que possibilitem o controle e também o consentimento periódico, bem como o acompanhamento da gestão governamental, por parte do Parlamento. ${ }^{24}$

O ano, conforme registra René Stourm, é considerado o período habitual das previsões humanas, e, em matéria orçamentária, mostra-se também o adequado como o máximo de tempo razoável para o parlamento autorizar os gastos, delegando poderes ao Executivo, e o mínimo de tempo necessário para os governantes executarem o orçamento. ${ }^{25}$ José Afonso da Silva também reconhece mais adequado o período anual para os orçamentos e o registro da atividade financeira do Estado:

23 Nesse sentido: CONTI, José Mauricio. O final de ano, as dívidas e os “restos a pagar". Veja-se também SILVA, José Afonso da. Orçamento-programa no Brasil, p. 132.

24 "Historiquement en effet, le principe a une justification politique. Les exigences du régime représentatif ont imposé une périodicité suffisamment brève pour garantir l'efficacité du contrôle parlementaire sur les finances de l'État. La règle du consentement périodique et limité, qui s'est d'abord appliquée aux impôts, devait permettre au Parlement de surveiller de façon stricte la gestion gouvernementale. C'est ainsi que la périodicité annuelle a fait partie de nos dogmes budgétaires" (BOUVIER, Michel. Programmation pluriannuelle et équilibre des finances publiques: les conditions du succès, p. 1).

25 "Puis l'année semble le maximum de temps pendant lequel les parlements puissent consentir à déléguer leurs pouvoirs, et le minimum dont les gouvernements aient besoin pour mettre le budget à exécution" (STOURM, René. Le budget, p. 311). 
"Considera-se que o período anual é o mais conveniente do ponto-de-vista político e financeiro. Primeiro, porque permite a aprovação e o contrôle político em períodos curtos. Segundo, porque um período mais amplo daria demasiada discrição ao govêrno na formação e execução do orçamento e um período menor que o ano não seria suficiente para reconhecer, contabilizar, arrecadar os tributos e comprometer, ordenar e pagar as despesas, além de ter a vantagem de conforma-se ao ciclo dos negócios privados - emprêsas industriais, comerciais, agrícolas - que se encerra anualmente, o que permite conhecer-lhes a situação econômica”. ${ }^{26}$

Admite-se que o princípio da anualidade orçamentária tenha origem no século XVII, por influência das práticas britânicas, associadas aos ideais da Revolução Francesa, pois reforça o controle do parlamento sobre o Poder Executivo e torna o orçamento mais democrático, aumentando o conhecimento, a vigilância e a possibilidade de limitação das ações governamentais. ${ }^{27}$

No entanto, a periodicidade anual da lei orçamentária é um princípio que está a exigir uma releitura, em face das distorções que sua aplicação causa ao processo orçamentário, e em face também da evolução experimentada nos atos relacionados com a atividade financeira do Estado. Veja, nesse sentido, não somente a posição de José Afonso da Silva, já mencionada, como também de outros autores, com destaque para a de Regis de Oliveira, para quem não há mais que se considerar a anualidade um princípio: "Tal princípio está hoje ultrapassado, porque, ao lado do orçamento anual, há o plurianual (...) (e) já não se pode tratar a anualidade como princípio”. ${ }^{28}$

Entre as várias distorções causadas pela rígida aplicação da anualidade orçamentária, estão os gastos "apressados" ocorridos no final do exercício financeiro, com a finalidade de esgotar as dotaçôes orçamentárias, evitando que sejam diminuídas por ocasião da elaboração do próximo orçamento, tornando definitiva a redução dos recursos. Em decorrência da adoção da técnica de "orçamento incrementativo" na elaboração orçamentária, é considerado, para o orçamento do exercício seguinte, na previsão dos recursos para cada dotação, o valor executado no exercício financeiro

26 SILVA, José Afonso da. Orçamento-programa no Brasil, p. 133.

27 Nesse sentido, o relato de Giuliani Fonrouge: "A partir del siglo XVII y por influencia de las prácticas británicas, el carácter anual del presupuesto llegó a constituir um principio indiscutido em las finanzas clásicas. Contribuyeron a su afianzamiento argumentos de orden político, ya que el sistema robustecia la facultad parlamentaria de controlar al ejecutivo, de modo tal que la práctica iniciada bajo forma de voto anual del impuesto, se transformó en un medio efectivo de conocer, vigilar y limitar la acción general del gobierno en la democracia clásica. La influencia ejercida por los principios liberales de la Revolución Francesa y la difusión de las instituciones políticas inglesas resultaron factores predominantes en la generalización del principio de la anualidade presupuestaria" (Derecho financiero, p. 172).

OLIVEIRA, Regis F. Curso de direito financeiro, p. 423. 
anterior. Isso tem gerado um incentivo aos gestores para gastar todo o dinheiro disponível antes do final do ano, ainda que de forma desnecessária, apenas para manter o valor contemplado na dotação vigente, ${ }^{29}$ gastos em regra de baixa qualidade. ${ }^{30}$

Imprescindível hoje a adaptação das previsões plurianuais ao sistema orçamentário anual, uma vez que a execução orçamentária se concretiza a partir da lei orçamentária, exigindo instrumentos que permitam a adequada ligação entre eles - as chamadas "correias de transmissão entre o plano e o orçamento", nas já citadas palavras de Cabral de Moncada.

Muitos são os instrumentos que permitem essa ligação, valendo citar alguns exemplos.

No Brasil, há previsão legal para os "restos a pagar", conforme art. 36 da Lei n. 4.320, de 1964, e art. 42 da Lei de Responsabilidade Fiscal (Lei Complementar n. 101, de 2000), permitindo que a Administração Pública se comprometa no final do ano a fazer pagamentos de despesas empenhadas no exercício, deixando-os para que se concretizem no exercício financeiro seguinte.

É o caso também do chamado carry-over, instrumento por meio do qual se estabelece que dotações possam ser "carregadas" para o exercício financeiro seguinte, mesmo após ultrapassado o exercício financeiro, permitindo que uma despesa seja feita em exercício diverso daquele para a qual for programada. ${ }^{31}$

Instrumento necessário, como destacam Lienert e Ljungman, tendo em vista as imperfeições e peculiaridades do processo orçamentário, que praticamente inviabilizam a observância de todos os itens do orçamento anualmente. ${ }^{32}$ Trata-se de instru-

29 Nesse sentido, veja-se texto de minha autoria comentando o assunto intitulado "Natal é tempo de correr com a execução orçamentária". Levando o direito financeiro a sério, p. 211-214.

30 Como reconhecem muitos autores. Daniel Alves em texto sobre o tema observa que são "gastos de qualidade questionável, vez que, dado o curto espaço de tempo em que são executados, muitas vezes não são seguidos todos os trâmites licitatórios e formais recomendados, e boa parte destes gastos acaba sendo realizada via dispensa de licitação ou via o instituto da carona” (Carry-over: a flexibilização do princípio da anualidade orçamentária como indutora da qualidade do gasto público e da transparência fiscal, p. 11). Sem contar o fato de, muitas vezes, serem desnecessários, já que o objetivo principal é esgotar a dotação.

31 "Carry-over is the right to use an unspent appropriation beyond the time period for which it was originally granted. This means that a spending agency can use some or all of what has not been spent of the previous years' appropriations in addition to the current year's budget allocation”, conforme definem Lienert e Ljungmann (Carry-over of budget authority, p. 2).

32 "The need for carry-overs arises because public sector budgeting is, in many ways, an imperfect process. The heterogeneous nature of government undertakings, information asymmetries, limited time and resources available for budget preparation, and complex approval procedures 
mento importante de adaptação das dotações de caráter plurianual para o sistema anual de execução orçamentária, com ganhos de eficiência na gestão, principalmente por evitar os gastos apressados no final do exercício financeiro, com a finalidade de esgotar as dotações consignadas, evitando-se que sejam reduzidas no exercício seguinte, em face do método incrementalista de elaboração orçamentária, como há pouco referido. E é uma falha comum em vários países, como bem observado por Jón Blöndal:

"All countries operate on the principle of an annual budget. Previously, this meant that all appropriations lapsed at the end of the fiscal year thus creating a great and irrational rush to spend money before the end of the fiscal year. Not only because they would otherwise lose the money that year, but also because future years' appropriations would take account of this under spending as well. You were losing what you did not spend in one year, permanently. This has now changed with operating expenditures generally being freely transferable (sometimes up to a certain limit) from one year to the next. Only in cases where an agency continuously, year-on-year, builds up carry-overs does the Ministry of Finance intervene. The advent of medium-term expenditure frameworks also gives a benchmark for agencies to see that their appropriations are in fact being carried-over". ${ }^{33}$

O tema voltará a ser tratado ao longo do trabalho, tendo em vista que, no mais das vezes, as técnicas de orçamento e planejamento orçamentário envolvem instrumentos voltados a estabelecer essa ligação entre os planos de natureza plurianual e os orçamentos anuais.

Destacar-se-á, a seguir, uma técnica em crescente uso e desenvolvimento, fundamental para essa ligação plano-orçamento, e que permite, também e principalmente, uma melhor adequação das previsões plurianuais com a gestão financeira contínua.

É o chamado "planejamento deslizante", ou, segundo alguns autores, "planejamento rolante". ${ }^{4}$

\subsection{PLANEJAMENTO DESLIZANTE}

Constata-se claramente nos dias de hoje um maior dinamismo existente nas relações sociais e econômicas, o que causa dificuldades para o planejamento orçamentário

in the executive and the legislature, make it difficult, if not impossible, to completely assess all items in the budget every year. Consequently, to some extent budget allocations have to be based on approximations and universally applied formulas" (LIENERT, Ian; LJUNGMAN, Gösta. Carry-over of budget authority, p. 2).

33 BLÖNDAL, Jón R. Budget reform in OECD member countries: common trends. OECD Journal on Budgeting, p. 24-25.

34 Planification glissante no direito francês. 
governamental, dada a necessidade de previsão de ações governamentais, com os respectivos custos, para o médio prazo, e das adaptações durante o curso da execução do planejamento, em face das alterações sempre presentes.

O sistema de planejamento orçamentário da administração pública, positivado no ordenamento jurídico, exige a especialmente difícil compatibilização entre segurança jurídica, com normas claras e eficazes, com a imprescindível flexibilização para as adaptações que se fazem necessárias em face das peculiaridades desse sistema.

A técnica de "planejamento deslizante" consiste em haver um planejamento de médio prazo, ${ }^{35}$ como é o caso dos planos plurianuais previstos em nossa legislação, compondo um sistema jurídico em que há normas prevendo a atualização, ano a ano, das previsões, de modo a permitir uma adaptação suave, em que se preservam os princípios do planejamento, mantendo-se a eficácia das normas vigentes.

A existência de mecanismos de planejamento deslizante é reconhecida e defendida pelos estudiosos do tema, como se vê principalmente nos trabalhos produzidos pela OCDE, que registra em muitos países a adoção de orçamentos de médio prazo, para períodos de três a cinco anos, incluindo o exercício financeiro. Esses documentos indicam aos atores envolvidos e interessados a direção da ação governamental e as formas de financiamento, permitindo que se adaptem a elas, e também ajudam a identificar onde e como se podem alocar novos programas. ${ }^{36}$ Jón Blöndal, ao analisar os "medium-term budget frameworks", em seu estudo sobre as reformas orçamentárias nos países da OCDE, destaca a estabilidade e a credibilidade proporcionada para as metas fiscais do governo, ${ }^{37}$ constatando ainda que esses documentos geralmente se espelham nos orçamentos, mantendo o mesmo nível de detalhamento, o que aumenta a eficácia do planejamento e facilita o processo de elaboração do orçamento anual, e frequentemente contêm previsões para

35 Ou longo prazo, mas este último se adapta tão somente ao planejamento econômico governamental, que não é o objeto deste estudo; daí a razão pela qual far-se-á referência ao planejamento de médio e curto prazos.

OCDE. Government at a glance 2009, p. 90.

37 "Medium-term budget frameworks form the basis for achieving fiscal consolidation. They need to clearly state the government's medium-term fiscal objectives in terms of high-level targets such as the level of aggregate revenue, expenditure, deficit/surplus, and debt. They then need to operationalise these high-level targets by establishing hard budget constraints for individual ministries and programmes over a number of years. This lends stability and credibility to the government's fiscal objectives" (BLÖNDAL, Jón R. Budget reform in OECD member countries: common trends, p. 10). 
três anos, além do exercício financeiro. ${ }^{38}$ Nazaré Cabral registra em Portugal a adoção, em dezembro de 1998, do Programa de Estabilidade e Crescimento (PEC) 1999-2000, sendo atualizado anualmente, "garantindo-se a sua implementação deslizante por cada ano de actualização" ${ }^{39}$

No sistema jurídico brasileiro, a Lei de Diretrizes Orçamentárias tem sido o instrumento de viabilização do planejamento deslizante, especialmente após a inclusão, pela Lei de Responsabilidade Fiscal, em seu art. $4^{\circ}, \$ \$ 1^{\circ}$ a $3^{\circ}$, dos anexos de metas e riscos fiscais, e do anexo com previsão de agregados fiscais (art. 165, $\$ 12^{\circ}$ ). O Banco Mundial dá destaque à utilização da LDO brasileira como instrumento da modalidade "medium-term framework" que tem sido útil para sinalizar o ajuste fiscal por meio da fixação das metas fiscais. ${ }^{40}$

A Lei de Diretrizes Orçamentárias, a partir da LRF, assumiu a responsabilidade de dispor sobre o equilíbrio entre receitas e despesas (LRF, art. 40, I, a), estando entre os instrumentos importantes para cumprir essa missão o Anexo de Metas Fiscais. Este passa a integrar o projeto de Lei de Diretrizes Orçamentárias, sendo nele "estabelecidas metas anuais, em valores correntes e constantes, relativas a receitas, despesas, resultados nominal e primário e montante da dívida pública, para o exercicio a que se referirem e para os dois seguintes" (LRF, art. $4^{\circ}, \$ 1^{\circ}$, grifo nosso). Com o Anexo de Riscos Fiscais, documento no qual "serão avaliados os

38 "Although the level of detail of such frameworks varies from country to country, they generally mirror the format of the budget, i.e. the medium-term frameworks are at the same level of detail as the annual budget. This means that a formal framework (or hard budget constraint) exists for each and every appropriation, most often for three years beyond the current fiscal year. (...) This has greatly increased the effectiveness of planning and eased the annual budget process. These frameworks are not, however, enacted into legislation; they are planning documents that reflect the political commitment to fiscal discipline" (BLÖNDAL, Jón R. Budget reform in OECD member countries: common trends, p. 11).

CABRAL, Nazaré da Costa. Programação e decisão orçamental. Da racionalidade das decisões orçamentais à racionalidade econômica, p. 599.

40 "The Budget Guidelines Law (LDO) is formulated every year, around April. It defines revenue, expenditure, and fiscal balance targets in a three-year rolling framework, thus classifying it as an MTFF. While its purpose is to link the PPA with annual budgets, this integration has not been successful, and the prioritization and resource allocations defined in the PPA have not been reflected in the annual budgets. The importance of the LDO has grown as a consequence of the strong fiscal adjustment implemented since 1999 and enactment of the Fiscal Responsibility Law (LRF) in 2000 (as a result of which the MTFF became fully functional in 2001). The LDO presents fiscal targets in terms of primary surpluses for three years (including the current budget year). These targets are crucial in signaling the government's fiscal adjustment efforts" (WORLD BANK. Beyond the annual budget. Global experience with medium-term expenditure frameworks, p. 193). 
passivos contingentes e outros riscos capazes de afetar as contas públicas, informando as providências a serem tomadas, caso se concretizem", constrói-se um sistema que permite garantir com maior segurança jurídica o avanço planejado das ações governamentais, de modo a asseverar a estabilidade e a sustentabilidade do desenvolvimento, com minimização dos riscos de desequilíbrios fiscais.

O que releva notar, nesse sistema, é que, sendo a LDO anual, e tendo o Anexo de Metas Fiscais a obrigação de estabelecer as metas anuais de receitas, despesas, resultados nominal e primário e montante da dívida pública, não somente para o exercício seguinte, mas também para os dois subsequentes, há, ainda que apenas nesses campos, uma previsão extremamente importante para o planejamento de médio prazo da ação governamental. Planejamento este que, pela periodicidade anual da LDO, renovar-se-á ano a ano, de modo que fica bem caracterizado o sistema de planejamento deslizante, recomendado para as mais modernas técnicas de planejamento e orçamentação, favorecendo a adaptação das alterações ocorridas no decorrer da execução de forma suave, não abrupta, flexibilizando adequadamente o planejamento, sem prejuízo à credibilidade e à segurança jurídica, fundamentais para a eficácia das normas que os veiculam.

Além disso, os próprios sistemas de monitoramento e avaliação dos planos plurianuais federais institucionalizaram mecanismos de planejamento deslizante, com a finalidade de aperfeiçoar a gestão do PPA. O Relatório Anual de Avaliação do PPA 2004-2207 registra a prática do "planejamento plurianual deslizante" em 2005:

"Anualmente, por meio do Relatório de Avaliação Anual, os programas e ações do PPA passam a contar com as estimativas de valores financeiros e metas físicas para os quatro exercícios subsequentes. Em 2005 o referido relatório traz a programação indicativa para o período 2006-2009. Esta é uma prática inovadora do processo de planejamento que permite a manutenção de um horizonte de médio prazo nas decisões tomadas no presente". ${ }^{41}$

Os sistemas que implantaram mecanismos viabilizando um planejamento deslizante aperfeiçoaram o planejamento orçamentário governamental de médio prazo, pois permitiram a indicação aos agentes econômicos e demais atores envolvidos das diretrizes e objetivos da administração pública, ao mesmo tempo que asseguraram mecanismos de adaptação às inevitáveis mudanças ocorridas nos cenários. A existência de documentos confiáveis, que sinalizam periodicamente

41 BRASIL. Ministério do Planejamento, Orçamento e Gestão. Secretaria de Planejamento e Investimentos Estratégicos. Relatório de avaliação do Plano Plurianual 2004-2007, p. 38. 
eventuais alterações de rumos, de forma suave previsível, com clareza e transparência, confere às normas de planejamento maior credibilidade, impedindo desvios bruscos do caminho traçado pelo ente ou órgão.

No Brasil, a técnica de planejamento deslizante mostra-se especialmente relevante em função de nossa organização federativa, sem coincidência de mandatos, e com a obrigação de cada ente da federação adotar seu planejamento de médio prazo, por meio dos planos plurianuais, em períodos não coincidentes.

\subsection{A LEI DE DIRETRIZES ORÇAMENTÁRIAS}

A Lei de Diretrizes Orçamentárias (LDO) merece especial atenção no sistema de planejamento orçamentário da administração pública brasileira.

Criada na Constituição de 1988 como mecanismo voltado a estabelecer um elo entre o PPA e a LDO, acabou assumindo relevância crescente como instrumento de planejamento orçamentário. Como já mencionado em texto de minha autoria, cumpre função relevante no sistema de planejamento da ação governamental, pois obriga os administradores públicos a definirem, a cada ano, quais programas previstos no plano plurianual serão contemplados e quanto se pretende realizar, evitando, com isso, deixar para o final do mandato cumprir os programas previstos no PPA, o que pode inviabilizar o alcance das metas fixadas. ${ }^{42}$

Surgiu como alternativa ao orçamento bianual, proposta cogitada por ocasião dos trabalhos da Assembleia Nacional Constituinte, em que se estabeleceria um orçamento válido por dois anos. Prevaleceu a proposta deste que é um verdadeiro "pré-orçamento", que permitiu ao Poder Legislativo ter uma participação mais efetiva na elaboração da lei orçamentária, ao integrar o processo de definição das prioridades e metas da administração para o exercício seguinte, função precípua da LDO. ${ }^{43}$

Teve suas atribuiçōes significativamente aumentadas pela Lei de Responsabilidade Fiscal, e hoje tem exercido um papel que se assemelha a um verdadeiro código de finanças públicas, com normas regulando anualmente vários aspectos do ciclo orçamentário, o que se constata até mesmo por sua crescente dimensão, tendo as mais recentes ultrapassado a centena de artigos. ${ }^{44}$

42 LDO é instrumento eficiente para a Administração Pública. Levando o direito financeiro a sério, p. 151-154.

43 AFONSO, José Roberto Rodrigues. Orçamento e finanças públicas na elaboração da Constituição da República de 1988, p. 18-19.

44 LDO federal 2017 - Lei n. 13.408, de 26.12.2016, 156 artigos; LDO federal 2016 - Lei n. 13.242, de 30.12.2015, 152 artigos; LDO federal 2015 - Lei n. 13.080, de 2.1.2015, 146 
Entre essas atribuições, algumas merecem destaque, ${ }^{45}$ como a regulamentação e o estabelecimento de critérios para limitação de empenho (LRF, art. 4º, I, b), permitindo que se organize o contingenciamento, estabelecendo regras e limites, evitando que o Poder Executivo, no exercício de sua função de comando na execução orçamentária, venha a descumprir a lei orçamentária, desviando-a de seu curso, frustrando a aplicação da lei que havia sido legitimamente aprovada e colocando freios aos abusos de há muito observados em matéria orçamentária, como se observa quando o Poder Executivo, fazendo uso do contingenciamento, superpõe-se indevidamente, e não democraticamente, aos demais Poderes e entes da federação, subjugando-os pela não liberação dos recursos previstos no orçamento.

E, ainda, as normas para controle de custos e avaliação dos resultados dos programas orçamentários (LRF, art. $\left.4^{\circ}, \mathrm{I}, c\right)$, fundamentais para que se consolide um sistema eficaz de planejamento e orçamento preocupado com o bom desempenho da administração pública, ao permitir que se estabeleçam regras claras para avaliação do cumprimento das metas, "asfixiando os desvios ilegítimos de recursos públicos pela sua destinação a programas de difícil mensuração, o que sempre facilitou a malversação de dinheiro público".

A fixação de condições e exigências para transferências de recursos a entidades públicas e privadas (LRF, art. $4^{\circ}, \mathrm{I}, d$ ) "é outro papel da maior relevância, pois a entrega de recursos orçamentários a terceiros, a fim de que atendam a finalidades públicas, é ato que tem se intensificado cada vez mais, da mesma forma que as fraudes que a ele se associam", e as LDO têm sido importantes instrumentos para coibir esses desvios.

Destaque-se ainda o Anexo de Riscos Fiscais (LRF, art. 4º $\$ 3^{\circ}$ ), que "obriga também os administradores públicos a pensar nos problemas futuros, exigindo que se preparem antecipadamente a eles e antecipem as medidas a serem tomadas caso venham a se concretizar, evitando as sempre presentes ações imediatas e improvisadas, resolvendo problemas ocorridos e que só tenderão a aumentar, fato mais que conhecido em toda a burocracia estatal".

artigos. Weder de Oliveira registra que, "vinte e cinco anos passados, a extensão textual das LDO ampliou-se em quase cinco vezes (mais de 450 artigos e parágrafos) em relação às primeiras" (Gênese, funcionalidade e constitucionalidade da Lei de Diretrizes Orçamentárias, p. 416).

45 Como mencionado em texto de minha autoria, "LDO é instrumento eficiente para a administração pública”, de 2013, ora em parte reproduzido, sem necessariamente a inserção de aspas em todos os trechos, tendo em vista pequenos ajustes e alteraçóes. 
Fundamental também tem sido a divulgação dos objetivos das políticas monetária, creditícia e cambial e as metas de inflação (LRF, art. $4^{\circ}, \$ 4^{\circ}$ ), de extrema relevância "para a transparência que se espera da administração pública, deixando claro, para o setor público, privado e a sociedade em geral, dos rumos que se pretende dar à ação governamental, o que é fundamental para que todos possam se orientar de forma coordenada e planejada”.

Especial destaque de interesse para esta tese é a presença do Anexo de Metas Fiscais (LRF, art. $4^{\circ}, \$ 1^{\circ}$ ), que prevê a fixação de metas para o exercício em curso e os dois subsequentes, a cada ano. Institui o já citado sistema de "planejamento deslizante" da ação governamental, em que as necessárias alterações e adaptações dessas normas passam a ser feitas de forma gradual e formal, mantendo a segurança jurídica e a confiabilidade do sistema. Com a avaliação e o acompanhamento das metas estabelecidas, por métodos precisos e transparentes, os gestores ficam impedidos de fazer delas números voltados apenas a cumprir formalidades burocráticas.

Mais recentemente, a Emenda Constitucional n. 102, de 2019, determinou que caberá à LDO ter anexo "com previsão de agregados fiscais e a proporção dos recursos para investimentos que serão alocados na lei orçamentária anual para a continuidade daqueles em andamento", para o exercício que se refere e para os dois exercícios financeiros subsequentes, um instrumento com potencial de ser muito útil para dar segurança jurídica em matéria orçamentária aos investimentos plurianuais e ao sistema de planejamento.

O sistema de metas estabelecido pela LDO tem importante caráter estruturante para o equilíbrio fiscal e, consequentemente, para o planejamento orçamentário, uma vez que o descumprimento delas "permite verificar, ainda que de forma indireta, a desobediência a uma série de outros deveres de equilíbrio fiscal previstos na LRF, não restringindo ao dever de cumprir as metas". Como ocorre no caso "das renúncias de receitas, cuja concessão tem como condição de validade para sua instituição a comprovação de não afetação das metas fiscais, o que, se ocorrer, deve ser compensado mediante a instituição de novo tributo ou majoração de alíquota ou base de cálculo de tributo já existente". E também a "criação, expansão ou aprimoramento de qualquer ação governamental que implique aumento de despesa está vinculada à compatibilidade com as metas fiscais, as quais - se forem afetadas por mais de dois exercícios por meio da geração de despesa definida em ato normativo - devem ser compensadas proporcionalmente por meio da redução permanente de despesa ou majoração permanente de receita”, o que evidencia este caráter estruturante da metas fiscais para o equilíbrio das contas públicas: "se elas não são 
cumpridas, todas as demais áreas de gestão de receita e de despesa são presumidamente irregulares, lesivas ao erário e não autorizadas, na forma do art. 15 da própria LRF”. 46

Embora possa ser considerado frustrante o desempenho da LDO em sua função de definição das grandes alocações e de orientação geral do orçamento, como bem observa Weder de Oliveira, em trabalho dedicado ao tema, ${ }^{47}$ sendo corroborado pelo TCU, ${ }^{48}$ há que se reconhecer ter sido o instrumento uma inovação bastante positiva em termos de aperfeiçoamento do sistema de planejamento orçamentário da administração pública brasileira, vendo-se a necessidade de que seja mais bem aplicado, a fim de que cumpra fielmente todas as funçôes para as quais foi criado e a Constituição lhe atribui.

\subsection{PLANEJAMENTO ORÇAMENTÁRIO E PLURIANUALIDADE NO BRASIL: A EVOLUÇÃO DOS PPA}

De todo o já exposto, vê-se estar o planejamento governamental associado a plurianualidade orçamentária, e a eficácia dos instrumentos de planejamento do setor público estreitamente vinculada às peças orçamentárias.

Desenvolvem-se, e estão em constante evolução desde os incipientes orçamentos públicos, sistemas, técnicas e métodos que procuram aperfeiçoar as previsões de longo, médio e curto prazos das ações governamentais, vinculando-as aos orçamentos, de modo a concretizá-las com segurança jurídica, previsibilidade, coesão e coordenação, fazendo com que produzam resultados da forma mais eficiente, eficaz e econômica.

O "faseamento" do planejamento governamental em quatro etapas (ou patamares), bem delineado por Nazaré Cabral, permite identificar claramente a contextualização e a importância da ligação que está presente no planejamento, na plurianualidade e no orçamento.

46 CONTI, José Mauricio. Acabar com a meta de superávit é irresponsabilidade fiscal. Levando $o$ direito financeiro a sério, p. 396.

47 OLIVEIRA, Welder de. Gênese, funcionalidade e constitucionalidade da Lei de Diretrizes Orçamentárias, p. 416.

48 No Relatório sobre as Contas de Governo de 2014, há a expressa constatação da irregularidade "Ausência do rol de prioridades da administração pública federal, com suas respectivas metas, no Projeto de Lei de Diretrizes Orçamentárias de 2014, descumprindo o previsto no $\$ 2^{\circ}$ do art. 165 da Constituição Federal", seguido da recomendação para que sejam incluídos (BRASIL. Tribunal de Contas da União. Relatório e parecer prévio sobre as contas do Governo da República. Exercício de 2014, p. 75). 
Sistematiza a autora o planejamento das despesas públicas em Portugal em quatro patamares: 1) planejamento de longo prazo das despesas, cuidando de fatores como envelhecimento demográfico, segurança social, saúde, preocupações com a "orçamentação social", e documentos como a Lei de Enquadramento Orçamental e a Lei de Bases da Segurança Social, que funcionam como documentos de programação e enquadramento de longo prazo, de modelização econômica, apoiados na construção de cenários. São instrumentos para a previsão de receitas e despesas de dimensão intergeracional; 2) programação macroeconômica de médio prazo, em que se elaboram e atualizam os programas de estabilidade e crescimento, a serem apresentados pelo Estado português às instâncias da Comunidade Europeia. Operam como elos entre os instrumentos de planejamento de longo prazo e a programação financeira de médio prazo (terceira etapa), já com informações mais detalhadas de dados sobre as finanças públicas; 3) Programação financeira de médio prazo. Há documentos administrativos de programação financeira plurianual, nem sempre dependentes de aprovação parlamentar, que servem como instrumento de orientação dos orçamentos anuais, com configuração plurianual deslizante (observar que se assemelham aos planos plurianuais brasileiros, que são instrumentos legais, e dependem de aprovação parlamentar); 4) Orçamentação, fase em que se definem e especificam as despesas no orçamento, regra geral anual, e que deve enquadrar-se na perspectiva plurianual definida nas etapas anteriores. Habitualmente, materializam-se em programas, associando-se às técnicas de orçamentação por objetivos, utilizando-se modelos que incorporam medidas de desempenho e avaliação de resultados, com maior controle e responsabilização. ${ }^{49}$

No cumprimento deste papel de elo entre o planejamento e o orçamento, há que se destacar os instrumentos de planejamento orçamentário de médio prazo, que são os mais relevantes para a finalidade de vincular as projeções do planejamento governamental em ações concretas descritas na lei orçamentárias e executadas ao longo do exercício financeiro.

No sistema brasileiro, o principal papel é desempenhado pelo Plano Plurianual, que tem a função precípua de estabelecer os objetivos, as diretrizes e as metas da administração pública para o período equivalente a um mandato, nos termos do art. 165 da Constituição, e fazer essa ligação entre os orçamentos e os instrumentos

49 CABRAL, Nazaré da Costa. Programação e decisão orçamental. Da racionalidade das decisões orçamentais à racionalidade econômica, p. 422-61 e destaque ainda ilustrativo no quadro na p. 436. 
de planejamento voltados ao desenvolvimento nacional e regional (Constituição, art. 174), viabilizando o alcance dos objetivos fundamentais da nossa República Federativa e da efetiva implantação dos direitos sociais.

O PPA é o principal instrumento constitucional voltado a resultados, estabelecendo os fins (no sentido de alterações desejadas na realidade), e a lei orçamentária estabelecendo os meios (despesas necessárias), cabendo à LDO estabelecer o vínculo entre elas. ${ }^{50}$

O Brasil tem experimentado uma evolução no que se refere ao aperfeiçoamento desses instrumentos, o que se pretende demonstrar a seguir, destacando-se seus principais aspectos, a partir do orçamento plurianual de investimentos, o mais próximo precursor dos atuais planos plurianuais, atualmente vigentes. Estes últimos têm ainda demonstrado evoluir a cada nova edição, evidenciando que, por não haver ainda sido estabelecido um formato rígido, dada a não regulamentação do instituto, ${ }^{51}$ está em busca do modelo ideal.

\subsubsection{O Orçamento Plurianual de Investimentos (OPI)}

O planejamento orçamentário plurianual brasileiro, no formato que mais se aproxima do hoje vigente, tem no Orçamento Plurianual de Investimentos sua origem, que pode ser encontrada inicialmente na Lei n. 4.320, de 1964. Dispunha, nos arts. 23 a 26, sobre as "previsões plurianuais", estabelecendo que "as receitas e despesas de capital serão objeto de um Quadro de Recursos e de Aplicação de Capital, aprovado por decreto do Poder Executivo, abrangendo, no mínimo, um triênio" (art. 23), instituindo à época um sistema de planejamento deslizante, pois o referido quadro deveria ser "anualmente reajustado acrescentando-lhe as previsões de mais um ano, de modo a assegurar a projeção contínua dos períodos” (art. 23, parágrafo único).

Adotava-se também a técnica de orçamento por programas, com metas e resultados ("Art. 25. Os programas constantes do Quadro de Recursos e de Aplicação de Capital sempre que possível serão correlacionados a metas objetivas em termos de realização de obras e de prestação de serviços. Parágrafo único. Consideram-se metas os resultados que se pretendem obter com a realização de cada programa”).

50 PAULO, Luiz Fernando Arantes. Plano plurianual. Teoria, prática e desafios para a sua efetividade, p. 92-94.

51 Uma carência normativa que tem gerado muitas limitações ao sistema de planejamento, como destacado por James Giacomoni no texto "Bases normativas do plano plurianual: análise das limitaçôes decorrentes da ausência de lei complementar”. 
A Constituição de 1967 contemplou o orçamento plurianual de investimentos no art. 60, parágrafo único: "As despesas de capital obedecerão ainda a orçamentos plurianuais de investimento, na forma prevista em lei complementar".

A Lei Complementar n. 3, de 7 de dezembro de 1967, em cumprimento ao disposto no art. 46, III, da Constituição de $1946,{ }^{52}$ conceituou os Planos Nacionais ${ }^{53}$ e os regulamentou, definindo a periodicidade quinquenal (art. $3^{\circ}$ ) e estabelecendo que os projetos a serem executados devem ordenar-se em programas setoriais e regionais (art. 40). Referida Lei Complementar definiu e regulamentou também os Orçamentos Plurianuais de Investimento. O Orçamento Plurianual de Investimento foi definido como "a expressão financeira dos programas setoriais regionais, consideradas, exclusivamente, as despesas de capital” (art. 5\%), abrangendo a periodicidade trienal (art. $6^{\circ}$ ), e elaborado na forma de orçamento-programa, especificando os programas, os subprogramas, os projetos, os objetivos e a indicação de recursos (arts. $6^{\circ}$ e $7^{\circ}$ ), ressaltando a importância dessa técnica orçamentária para o planejamento orçamentário governamental à época.

O OPI era dotado de maior maleabilidade que os atuais PPA por conta do art. $9^{\circ}$, que permitia ao Poder Executivo, desde que justificadamente, propor anualmente ao Congresso Nacional o reajuste do OPI, que poderia compreender, nos termos das alíneas do artigo: a) inclusão de novos projetos; b) alteração dos existentes; c) exclusão dos não iniciados, comprovadamente inoportunos e inconvenientes (ou seja, dentro da análise do mérito administrativo dos atos administrativos discricionários); e d) retificação dos valores das despesas previstas.

A Lei Complementar n. 3 foi revogada pelo Ato Complementar n. 43, ${ }^{54}$ de 29 de janeiro de 1969 (parcialmente modificado pelo Ato Complementar n. 76, de 21 de outubro de 1969, e pela Lei Complementar n. 9, de 11 de dezembro de 1970), que fixou normas para a elaboração dos Planos Nacionais de Desenvolvimento,

52 "Ao Congresso Nacional, com a sanção do Presidente da República, cabe dispor, mediante lei, sobre todas as matérias de competência da União, especialmente planos e programas nacionais, regionais e orçamentos plurianuais".

53 "Art. 2o Entende-se por Plano Nacional o conjunto de decisões harmônicas destinadas a alcançar, no período fixado, determinado estágio de desenvolvimento econômico e social."

54 Os Atos Complementares foram normas baixadas pelo Presidente da República, sob a vigência da Constituição de 1967, alterada pelos Atos Institucionais (no caso, especificamente, o Ato Institucional n. 5, de 13 de dezembro de 1968), impostos pelo governo da época, que os autorizava quando decretado recesso do Congresso Nacional, permitindo-lhe "legislar em todas as matérias e exercer as atribuiçōes previstas nas Constituiçôes” (AI n. 5, de 1968, art. 2º, $\$ 1^{\circ}$ ), baseado no fundamento de que "a revolução vitoriosa se investe no exercício do Poder Constituinte" (AI n. 1, de 9 de abril de 1964). 
vinculando sua execução ao Orçamento Plurianual de Investimentos. Mantiveram-se a periodicidade trienal e a restrição às despesas de capital, subordinando-os às diretrizes e aos objetivos dos PND (art. $5^{\circ}$ ). Estabelece ainda que o Orçamento Plurianual de Investimento compreende as despesas de capital de todos os Poderes, órgãos e fundos, tanto da administração direta quanto indireta. ${ }^{55}$ A elaboração do OPI evidencia a preocupação com a execução do plano, como registra Fernando Rezende, ${ }^{56}$ e vê-se que a materialização em normas orçamentárias é uma necessidade para a concretização das medidas previstas em qualquer plano.

Interessante e relevante notar que o Ato Complementar n. 43 expressamente subordinava os orçamentos dos entes subnacionais aos orçamentos plurianuais de investimento (art. $\left.9^{\circ}\right)$.

O Orçamento Plurianual de Investimentos para o período de 1968 a 1970 surgiu com a Lei n. 5.450, de 5 de junho de 1968, estimando despesas de capital para o referido período no montante de NCr\$17.567.247.774,00 (dezessete bilhões, quinhentos e sessenta e sete milhões, duzentos e quarenta e sete mil, setecentos e setenta e quatro cruzeiros novos), especificando as fontes de recursos (orçamentários, próprios, externos e outros) (art. $2^{\circ}$ ) e discriminando por programas setoriais $\left(\operatorname{art.} 3^{\circ}\right)$.

O primeiro Plano Nacional de Desenvolvimento (PND) foi instituído pela Lei n. 5.727, de 4 de novembro de 1971, para o período de 1972 a 1974, sendo seguido pelo Orçamento Plurianual de Investimentos para o mesmo período, instituído pela Lei n. 5.753, de 3 de dezembro de 1971. O OPI 1972-1974 estimou despesas de capital no montante de Cr\$ 53.517.076.600,00 (cinquenta e três bilhões, quinhentos e dezessete milhões, setenta e seis mil e seiscentos cruzeiros), especificando-os por fontes (art. $2^{\circ}$ ), setores e órgãos (art. $3^{\circ}$ ), contendo também os anexos a discriminação dos programas.

O Orçamento Plurianual de Investimentos para o período de 1975 a 1977 estimava as despesas de capital no montante de Cr\$ 185.105.189.900,00 (cento e oitenta e cinco bilhões, cento e cinco milhões, cento e oitenta e nove mil e novecentos cruzeiros); o OPI 1978-1980, no montante de Cr\$564.415.854.000,00 (quinhentos e sessenta e quatro bilhões, quatrocentos e quinze milhões, oitocentos e cinquenta e quatro mil cruzeiros).

55 O que não foi integralmente observado, como registra José Afonso da Silva, tendo o OPI para o triênio 1972-1974 incluído despesas correntes (Orçamento-programa no Brasil, p. 83).

56 REZENDE, Fernando. Planejamento no Brasil: auge, declínio e caminhos para a reconstrução, p. 6. 
Os orçamentos plurianuais de investimentos, consoante se depreende do art. $5^{\circ}$ da Lei Complementar n. 3/1967, já transcrito anteriormente, tinham a função de estabelecer a correlação entre os planos (no caso, os PND, a partir de 1971), e os orçamentos, dando-lhes a expressão financeira dos programas, cumprindo o importante papel de integração planejamento-orçamento.

A partir da década de 1980, perdeu muito de sua função - que nunca chegou a ser plenamente exercida -, em razão da elevada inflação que se fez presente na economia nacional. Mostrou-se, no entanto, um precursor dos atuais planos plurianuais. Vale registrar nesse sentido a posição de Ronaldo Garcia, quando, ao discorrer sobre o PPA 2000-2003, afirma que o PPA não se mostra muito diferente dos OPI, cuja ideia era permitir a integração plano-orçamento, e cumpriram, "não muito satisfatoriamente, esse papel durante pouco mais de uma década (de 1968 a início dos anos 1980), após o que a escalada inflacionária lhe retirou previsibilidade e capacidade orientadora". ${ }^{7}$

\subsubsection{Os planos plurianuais federais (PPA) e sua evolução ${ }^{58}$}

Neste item, far-se-á uma análise da evolução do planejamento orçamentário da ação governamental experimentada pelo Brasil a partir da criação dos PPA, principal instrumento jurídico dessa modalidade de planejamento.

Os planos plurianuais representam indiscutivelmente papel central no sistema de planejamento orçamentário da administração pública, uma vez que, além de serem o instrumento por excelência de materialização do planejamento dos entes federados no aspecto orçamentário, conduzindo todas as demais normas do sistema - Lei de Diretrizes Orçamentárias e Lei Orçamentária Anual -, tornam-se o elo entre as demais normas de planejamento governamental e o orçamento público, permitindo que se concretize o conteúdo das referidas normas de planejamento nas ações que dependam de recursos para se viabilizar.

A Lei do Plano Plurianual, da forma como hoje se apresenta, foi instituída pela Constituição de 1988, art. 165, I e $\$ 1^{\circ}$, quando atribuiu ao Poder Executivo

57 GARCIA, Ronaldo Coutinho. A reorganização do processo de planejamento do governo federal: o PPA 2000-2003, p. 11.

58 Os itens que seguem são em parte baseados em texto de minha autoria, que foi ampliado, revisado, corrigido e aperfeiçoado, havendo eventuais trechos com redação igual ou semelhante. Deixamos de inserir aspas nos referidos trechos para dar maior fluidez ao texto, ficando registrada a referência à fonte: CONTI, José Mauricio. O plano plurianual - PPA. In: MARTINS, Ives G. S.; MENDES, Gilmar F.; NASCIMENTO, Carlos V. (Coord.). Tratado de direito financeiro. V. 1. São Paulo: Saraiva, 2013, especialmente p. 328-337. 
a iniciativa de dispor sobre o Plano Plurianual, que "estabelecerá, de forma regionalizada, as diretrizes, objetivos e metas da administração pública federal para as despesas de capital e outras delas decorrentes e para as relativas aos programas de duração continuada".

Serão feitas as referências consideradas relevantes, analisadas por períodos de vigência dos PPA, com ênfase nos referidos instrumentos. Desde a Constituição, foram elaborados sete planos plurianuais no âmbito federal, sobre os quais se discorrerá a seguir. Nesses períodos, dar-se-á destaque, eventualmente, quando cabível e pertinente, aos outros instrumentos jurídicos relevantes, especialmente as leis de diretrizes orçamentárias, bem como as leis orçamentárias anuais, e eventuais outros que se mostrarem relevantes.

Além deles, registre-se a existência de outros planos governamentais de natureza plurianual, como o Plano Nacional Decenal de Educação, previsto no art. 214 da Constituição, entre outros, que serão analisados oportunamente. As consideraçôes a seguir, no entanto, restringem-se aos que se caracterizam formalmente como planos plurianuais, nos exatos termos do art. 165, I, da Constituição, e eventualmente, se pertinente, serão feitas referências aos mencionados planos.

\subsubsection{O Plano Plurianual 1991-1995 (e a revisão 1993-1995)}

O primeiro plano plurianual nos moldes estabelecidos pela Constituição de 1988 veio com a Lei n. 8.173, publicada em 31 de janeiro de 1991, elaborada no governo do presidente Fernando Collor, eleito em 1989 e empossado em março de 1990. Dispôs sobre o Plano Plurianual para o período de 1991 a 1995.

Em cumprimento ao disposto no art. $165, \$ 1^{\circ}$, da Constituição, cuidou de estabelecer, para o quinquênio 1991-1995, as diretrizes, os objetivos e as metas da Administração Pública Federal.

Estabeleceu desde logo que haveria uma revisão a ser feita no meio do período, por meio de outra lei, que deveria ser encaminhada ao Congresso Nacional na abertura da sessão legislativa de 1992 (art. 5). Esta revisão se concretizou na Lei n. 8.446, de 21 de julho de 1992, com as previsóes para o período de 1993 a 1995.

As dificuldades previsíveis dessa nova experiência de planejamento, com a edição do primeiro plano plurianual, foram intensificadas pelo período conturbado da época, marcado por dificuldades econômicas e principalmente políticas, que culminaram no impeachment do presidente eleito Fernando Collor, interrompendo seu mandato no meio, sendo substituído pelo vice-presidente Itamar Franco. 
A grande inflação, que não conseguiu ser controlada na primeira parte do mandato, acabou por prejudicar as atividades relacionadas com o planejamento orçamentário no restante do mandato cumprido pelo vice-presidente. A instabilidade econômica causada pela inflação marcou negativamente esse período, sendo um fator determinante para prejudicar as atividades associadas ao planejamento da atividade governamental, que se torna inviável em um quadro com essas características.

Isso impediu que o primeiro PPA pudesse ser considerado uma experiência exitosa, não sendo possível reconhecer ter havido um efetivo planejamento, com objetivos e metas claros, que tenham sido adequadamente avaliados, acompanhados e cumpridos ao final do período.

Ronaldo Garcia critica a improvisação do plano, afirmando ter sido um verdadeiro "OPI ampliado", e "sem estar suportado por um projeto de governo preciso para o qual fizesse a mediação com os orçamentos anuais”, com os responsáveis pela elaboração não mantendo contato regular com os dirigentes máximos, e estes transmitindo declaraçôes com intenções vagas, programas "com nomes pomposos e sem substância”, sem indicação de como implementá-los na prática. Um plano que apenas teve a função de cumprir a exigência constitucional, apresentado ao Congresso Nacional e aprovado praticamente sem discussões, que "não se tornou um orientador da ação governamental". 59

Soma-se a isso a característica do primeiro PPA, em que os objetivos e as metas mostraram-se abrangentes, pouco específicos, o que veio a se corrigir gradativamente a partir dos planos subsequentes.

Este plano plurianual identificou a redução da capacidade de investimentos por parte do setor público ocorrida na década anterior, bem como a situação de descontrole das contas públicas, tornando necessária a reestruturação das finanças do governo federal, estabelecendo a necessidade de retomada do crescimento, por meio de um ajuste fiscal e de equilíbrio orçamentário (Lei n. 8.173, Anexo I). Mostrou a necessidade de uma reforma administrativa para que o Estado pudesse cumprir um novo papel na retomada do crescimento, implementando grandes projetos de investimento em infraestrutura que o setor privado não teria condições de assumir, para o que se fazia necessária a construção de um Estado moderno e eficiente.

O PPA 1991-1995 inicia conceituando diretrizes, objetivos e metas, o que é relevante, na medida em que, como se pode observar, esses conceitos foram se

59 GARCIA, Ronaldo Coutinho. A reorganização do processo de planejamento do governo federal: o PPA 2000-2003, p. 24. 
aperfeiçoando ao longo do tempo e acompanhando a evolução das técnicas e nomenclaturas utilizadas na administração pública para a orçamentação e o planejamento.

As diretrizes são definidas como "o conjunto de critérios de ação e de decisão que deve disciplinar e orientar os diversos aspectos envolvidos no processo de planejamento" (art. $1^{\circ}, \$ 1^{\circ}, I$ ); objetivos correspondem aos "resultados que se pretende alcançar com a realização das ações governamentais" (art. $1^{\circ}, \$ 1^{\circ}$, II); e metas são "a especificação e a quantificação física dos objetivos estabelecidos" (art. 1º, $\$ 1$, III).

Em razão da inflação descontrolada na época, o PPA previa a sua própria revisão para "ajustamento às circunstâncias emergentes no contexto social, econômico e financeiro". Tanto é que estava completamente "indexado" a índices mensuradores de inflação, conforme expressamente previsto no art. 40. ${ }^{60}$ Também a revisão do PPA visava a continuar o "processo de reestruturação do gasto público federal" (art. $\left.5^{\circ}, \$ 1^{\circ}\right)$. A preocupação com a inflação mostra-se presente em outros dispositivos, como se vê do art. 20 ("Art. $2^{\circ}$ Os valores constantes dos anexos desta lei estão orçados a preços de fevereiro de 1992. Parágrafo único. As leis de diretrizes orçamentárias para os exercícios de 1993 a 1995 estabelecerão, para fins de elaboração dos orçamentos anuais, o índice que servirá para atualização dos valores de que trata este artigo").

A preocupação com a reestruturação do gasto público é expressa no art. 50, $\$ 2^{\circ}$ (Lei n. 8.173, de 1991), em que se fixaram os objetivos básicos do plano, entre os quais se destacam a busca do equilíbrio das contas públicas, o aumento do investimento público federal na área social e em infraestrutura, a revisão do papel regulador do Estado para consolidar uma economia de mercado moderna e o aumento da eficiência do gasto público. Evidenciava a adoção de uma política liberal, com a adoção de políticas de privilegiar as iniciativas e a capacidade gerencial do setor privado (Lei n. 8.173/1991, art. 5º, $\$ 2^{\circ}, c$ ), a consolidação da economia de mercado (Lei n. 8.173/1991, art. $5^{\circ}, \$ 2^{\circ}, d$ ) e as privatizaçôes (Lei n. 8.173/1991, art. $\left.5^{\circ}, \S 3^{\circ}, c\right)$. Também indicava a necessidade de descentralização, revendo a distribuição dos gastos com os entes subnacionais (Lei n. 8.173/1991, art. 5o, $\$ 2^{\circ}$, $f$ ), transferindo-lhes encargos (Lei n. 8.173/1991, art. 50, $\$ 3^{\circ}, e$ ).

60 "Os valores financeiros - despesas e necessidades de recurso - contidos nesta lei estão orçados a preços vigentes em maio de 1990 e serão atualizados, em cada exercício de vigência do Plano Plurianual, pela variação entre o valor médio no exercício, do Índice de Preços ao Consumidor (IPC), do Instituto Brasileiro de Geografia e Estatística (IBGE), e o valor do IPC do mês de maio de 1990." 
Os objetivos da reestruturação do gasto público federal eram orçamentários e administrativos. Constituíam objetivos orçamentários: (i) equilíbrio nas contas públicas; (ii) aumento dos níveis de investimento público federal (destinados à área social e infraestrutura econômica); (iii) dar racionalidade ao gasto público, bem como austeridade; e (iv) aumento de eficiência do gasto público.

Os objetivos administrativos consistiam em: (v) ajuste das políticas públicas federais às novas ideias de Estado gerencial; e (vi) revisão do papel de Estado regulador.

Vê-se haver, na época, forte preocupação com o equilíbrio nas contas públicas, problema extremamente presente e responsável pela grande dificuldade em conduzir a administração pública de forma planejada. Já estava presente a preocupação com a eficiência do gasto público e o ajuste das políticas públicas às novas ideias de Estado gerencial, bem como a necessidade de aumento nos investimentos sociais e de infraestrutura. No âmbito do planejamento econômico, destaca-se o objetivo de revisão do papel do Estado regulador da atividade econômica.

O PPA define "linhas de ação" destinadas a atingir os objetivos fixados, como a que vem disposta no $₫ 3^{\circ}$, $a$, do art. $5^{\circ}$, que prevê a redução da participação relativa dos gastos com pessoal nas despesas públicas federais, já antevendo o que viria a ser um dos pilares nos quais se fundou o sistema de gestão fiscal responsável, que veio a se concretizar de maneira mais clara e efetiva com a Lei de Responsabilidade Fiscal, em 2000.

Releva notar as preocupações com a questão federativa, presente em grande parte das mais importantes políticas públicas, no mais das vezes de caráter nacional, implantadas de forma a serem financiadas e executadas em regime de federalismo cooperativo, o que invariavelmente traz questóes jurídicas e administrativas complexas para serem administradas, e cuja boa coordenação é fundamental para o seu sucesso.

Aparecem já no art. $5^{\circ}, \S 2^{\circ}, f$, quando, ao tratar das medidas para a reestruturação do gasto público federal, pretende a elevação do nível de eficiência do gasto público, "mediante melhor discriminação e maior articulação dos dispêndios efetivados pela União, pelos Estados, pelo Distrito Federal e pelos Municípios”, e no mesmo artigo, $\$ 3^{\circ}$, $e$, a "transferência de encargos públicos para os Estados, Distrito Federal e Municípios”.

O PPA 1991-1995 estruturou-se em quatro anexos, sendo o primeiro deles destinado a estabelecer as Diretrizes e Objetivos Gerais; o segundo cuidou das Diretrizes e Metas Setoriais; o terceiro com a Relação de Projetos Prioritários; e o quarto contendo os Quadros das Despesas. 
O Anexo I, com as Diretrizes e Objetivos Gerais, traça as premissas macroeconômicas para a elaboração do PPA: redução dos investimentos públicos; reordenação das finanças públicas; geração de poupança pública e retomada do crescimento; definição das bases do ajuste fiscal da União; e evolução do Orçamento Geral da União (OGU) para fins de expansão da receita tributária.

Constata-se, na análise do cenário macroeconômico no qual se insere o plano, a deterioração da capacidade governamental de realizar investimentos produtivos, em razão principalmente da crise da dívida externa na década de 1980 (Anexo I, p. 1). O desequilíbrio das contas públicas acabou produzindo seus principais efeitos justamente nos investimentos públicos, dada a dificuldade de reduzir as outras categorias de despesas, como os gastos com pessoal, item que passou a sofrer forte contenção em 1991. Ajustes nas contas públicas por meio de privatizações também representaram pontos relevantes da política governamental. No PPA 1991-1995, vê-se uma preocupação com a necessidade de reorganização do Estado, que se entendia com excessiva intervenção na atividade econômica, atuando na produção e regulamentando de forma exagerada os mercados, inibindo seu funcionamento e sendo um obstáculo ao crescimento (Anexo I, p. 12). Direciona-se a ação governamental para a transferência ao setor privado do processo de desenvolvimento, com o saneamento da ação estatal por meio da estratégia de privatização das empresas estatais (Anexo I, p. 13).

A reforma da administração pública é vista como prioridade, tendo como princípios aumentar a eficiência do setor público e readequar as estruturas organizacionais do Estado, recuperando-se sua capacidade de gestão (Anexo I, p. 14). Há um reconhecimento da ineficiência do gasto público:

"A política social brasileira tem sido, frequentemente, ineficiente e ineficaz. Por uma parte, muito do chamado gasto social - que, representando $18 \%$ do PIB nos anos recentes, poderia ser encarado acriticamente como de montante adequado - não possui, na verdade, tal caráter, quando se examinam seus beneficiários reais. Boa parcela do gasto educacional, habitacional e de seguridade tem, de fato, beneficiado camadas relativamente privilegiadas da população, e não as que estão na faixa de pobreza”.

Ineficiência esta que se depreende ser decorrente da má administração e do planejamento deficiente:

"Por outra parte, os dispêndios sociais têm sido excessivos, se cotejados com seus resultados. Os efeitos das medidas são modestos e, muitas vezes, discutíveis quanto ao impacto efetivo na solução dos problemas. Os órgãos públicos têm atuado muitas vezes com base em diagnósticos falhos e em estatísticas descuradas, que levam a um dimensionamento impróprio dos programas. Caso notório tem sido o das estimativas de evasão escolar e de população fora da rede educacional, que induzem à mera 
construção ou ampliação de escolas, enquanto permanecem os problemas reais de repetência e lenta progressão ao longo das séries escolares" (Anexo I, p. 28).

Pretende-se buscar maior eficiência estatal com o uso de novas teorias gerenciais, aumentando-se a flexibilidade das estruturas burocráticas, reduzindo-se a departamentalização e desenvolvendo-se pensamento estratégico (Anexo I, p. 15-16).

A abertura da economia ao comércio exterior e os incentivos à maior inserção da economia brasileira no mercado mundial, com medidas de política fiscal, monetária e de desburocratização, além de políticas industriais de reaceleração dos investimentos e de modernização tecnológica, com melhoria na competitividade e na qualidade na indústria, foram pontos destacados no PPA 1991-1995.

Projeta-se uma intensificação do papel do Estado na área social, reduzindo-se sua atuação nas áreas produtivas, tornando mais efetivos os direitos de cidadania, buscando-se eliminar a pobreza e a miséria e protegendo-se os setores e as classes historicamente mais desamparados, especialmente pela melhoria na educação (Anexo I, p. 27-30).

Destacam-se ainda medidas de política agrícola, de meio ambiente e de desenvolvimento regional.

Entre as medidas para promover o desenvolvimento regional, com vistas a também diminuir as desigualdades, interessa destacar que as estratégias para viabilização incorporarão o aperfeiçoamento de instrumentos de coordenação de programas e orçamentos, de modo que esse objetivo "será viabilizado pelos planos nacional e regionais de ordenação territorial, pela articulação intersetorial nos complexos econômico-sociais, pela adoção de normas para a cooperação intergovernamental, e, por fim, pela regionalização de objetivos, metas e orçamentos, segundo critérios populacionais" (Anexo I, p. 36). A utilização de fundos constitucionais de orientação regionais passa a ser um instrumento útil para ações de caráter regional, colaborando para aumentar a transparência orçamentária no aspecto regional (Anexo I, p. 37).

O Anexo II contempla as diretrizes e metas setoriais, organizadas por poderes e órgãos do governo federal, com descriçōes, em cada uma, de suas diretrizes e objetivos, muitos deles já com metas quantificadas de forma detalhada para o período.

O Anexo IV, Quadro de Despesas, detalha os valores, por Poder e órgão, dos valores monetários para as despesas correntes e de capital, e programas de duração continuada, nos termos do que prevê o art. 165, $₫ 1^{\text {o }}$, da Constituição Federal, deixando transparecer no Plano Plurianual uma forte conotação orçamentária, dando-lhe o caráter de um verdadeiro orçamento plurianual. 
Com a Lei n. 8.446, de 1992, materializa-se a revisão do PPA 1991-1995, desta feita com validade para a segunda metade do período, valendo para o período de 1993 a 1995.

A revisão materializada no PPA 1993-1995 definiu as prioridades governamentais, aspecto de grande relevância em termos de planejamento, especialmente em situação de escassez, mostrando em que setores concentrar-se-ão as alocaçóes de recursos. Estabelecer e tornar claras as prioridades são das tarefas mais difíceis e relevantes em matéria de planejamento, dada a resistência em tornar claros as áreas e os setores que serão privilegiados, o que importa na politicamente indesejada tarefa de deixar transparecer o que ficará relegado a um segundo plano, gerando as previsíveis insatisfaçóes. São, no entanto, fundamentais, uma vez que a função planejadora tem na definição das prioridades o ponto a partir do qual se desdobrarão as demais atividades, que culminarão na especificação dos programas e das respectivas ações e destinação de recursos para que sejam implementadas.

O Anexo I da revisão do PPA 1993-1995 evidencia isso com clareza: "A programação plurianual, elaborada pelos diversos órgãos e unidades orçamentárias da Administração Pública Federal, ao nível de subprogramas, projetos e atividades mais relevantes, está vinculada às ações de governo decorrentes dessas prioridades, representando etapa metodológica ao estabelecimento de processo unificado de alocação de recursos, dentro de uma concepção de planejamento estratégico". Nesse trecho, é importante ressaltar a importância dada às prioridades, cuja definição é essencial para o planejamento plurianual. Destaque-se também a referência ao planejamento estratégico, que já aparece mencionado nesse PPA, e sua implantação se intensificará nos PPA posteriores, sendo acolhido de forma clara no PPA 2012-2015. ${ }^{11}$ E segue: "A definição de prioridades não implica, contudo, exclusão de outras áreas e programas de governo, alguns até muito importantes”, em que se vê o cuidado em evitar desgastes políticos, como observado anteriormente, em decorrência de a definição de prioridades importar em relegar a plano secundário as áreas e os setores não contemplados. E deixa claro o que se compreende por prioridade:

"Conceder prioridade significa destacar e enfatizar o eixo central de alocação dos recursos, de acordo com as diferentes características de cada segmento prioritário, mas sem abandonar, evidentemente, o conjunto das atividades necessárias do setor públi-

${ }^{61}$ A referência à adoção de planejamento estratégico aparece logo em seguida: "Na estrutura desses quadros incorpora-se o acervo conceitual de planejamento estratégico, que privilegia a abordagem por problemas, os quais, na maioria das vezes, são intersetoriais, exigindo, portanto, ação coordenada de planejamento". 
co, de natureza complementar e até mesmo rotineira, detalhada nas propostas de dispêndio dos Ministérios e órgãos da Presidência da República. (...) Em resumo, as prioridades de governo indicam ações de caráter estrutural, indutoras do desenvolvimento que deve modelar o futuro econômico-social do País". ${ }^{62}$

Estruturou-se em três anexos, sendo o primeiro destinado a elencar as prioridades do Governo, o segundo a estabelecer as diretrizes, objetivos, metas setoriais e a programação da despesa, e o terceiro com o exame das perspectivas, o estabelecimento de estratégias e a explicitação das premissas utilizadas para a revisão efetuada. Vê-se ainda uma preocupação com o acompanhamento e a avaliação da execução do plano, para o que se faz uso da Lei de Diretrizes Orçamentárias.

Em função do contexto e das condições do País no início da década de 1990, considerou-se necessário fixar prioridades para o período de 1993 a 1995, de forma a direcionar, de modo preciso, a ação governamental.

Foram eleitas as seguintes prioridades para o período:

a) educação, saúde, ciência e tecnologia, abrangendo ação integrada para a criança e o adolescente, melhoria da qualidade da educação básica, capacitação científica e tecnológica e consolidação do Sistema Único de Saúde;

b) reforma agrária e incentivo à produção agrícola;

c) recuperação e conservação do meio ambiente rural e urbano, envolvendo o zoneamento ecológico-econômico para a ordenação do território nacional sob esse enfoque;

d) consolidação e recuperação da infraestrutura;

e) abertura e modernização da economia (Anexo I, p. 6).

As cinco prioridades são extraídas de 23 referências de longo prazo definidas no Anexo III ("Estratégia de Desenvolvimento) e passaram a ser a atividade nuclear e central da ação governamental. As prioridades são definidas como de "programação e acompanhamento sistemático, até o nível da Presidência da República" (Anexo I, p. 6).

Já neste documento, começa a se delinear de forma mais precisa a ideia de planejamento estratégico, que foi sendo desenvolvida e aperfeiçoada até os planos plurianuais mais recentes. "Na estrutura desses quadros incorpora-se o acervo conceitual do planejamento estratégico, que privilegia a abordagem por problemas, os quais, na maioria das vezes, são intersetoriais, exigindo, portanto, ação coordenada de planejamento" (Anexo I, p. 6).

62 Lei n. 8.446/1992 (Revisão PPA 1993-1995), Anexo I, p. 6-7. 
Para permitir que as prioridades fixadas no Plano Plurianual sejam o mais fielmente respeitadas nos orçamentos anuais correspondentes ao período do plano, adotou-se a sistemática de discriminação em nível de projeto ou atividade, incluindo metas físicas, alocações financeiras e perfis regionais do gasto, segundo a classificação funcional-programática (Anexo II, p. 17).

O Anexo III expõe os desafios e as potencialidades do Brasil, a estratégia de desenvolvimento e as premissas do Plano Plurianual, sendo possível ver nele claramente o papel de instrumento fundamental para a concretização dos objetivos nacionais fixados no âmbito do planejamento econômico governamental, transformando-os em ações governamentais concretas a serem precisamente delimitadas nos orçamentos anuais.

Observe-se que isso fica bem claro no próprio documento, no texto do Anexo III, ao dizer que:

“o Plano Plurianual é instrumento que explicita a visão do Governo quanto ao desenvolvimento do País. Nesse sentido, representa uma agenda para negociações e articulaçôes dos atores sociais e dos agentes econômicos, e pretende estimular a convergência de ações e iniciativas tanto de instâncias públicas quanto de instituições e segmentos privados. Além disso, estabelece a programação das ações governamentais para o período, inclusive no que diz respeito à alocação dos recursos orçamentários e dos investimentos das empresas estatais. Este Plano é também um mecanismo de coordenação das ações de governo, subordinando-as à estratégia de desenvolvimento. A partir da análise dos desafios, problemas e potencialidades do Brasil neste fim de século, bem como das expectativas de desenvolvimento e bem-estar da sociedade brasileira, o Governo formula estratégias globais de médio e longo prazos. Delimitadas pelas disponibilidades de recursos para o período 1993-1995, as estratégias traduzem-se em prioridades, orientando as ações governamentais, realisticamente, para o curto e médio prazo. Essas prioridades manifestam-se sob a forma de alocação dos recursos orçamentários do setor público federal, o principal - mas não o único - instrumento da ação para o desenvolvimento" (Anexo III, p. 213, grifo nosso).

Destacaram-se seis estratégias propostas pelo Governo para o terceiro milênio: educação, ciência e tecnologia para o desenvolvimento; modernização da produção; crescimento e distribuição de renda; sustentabilidade do desenvolvimento; equalização de oportunidades; modernização do Estado (Anexo III, p. 218).

Para alcançá-las, foram estabelecidas prioridades em cada estratégia de desenvolvimento, a seguir enumeradas:

Para a educação, ciência e tecnologia para o desenvolvimento: a) melhoria da qualidade da educação básica; b) ciência e tecnologia; e c) valorização de recursos humanos em educação, ciência e tecnologia. 
Para a modernização da produção: a) abertura e modernização da economia; b) capacitação tecnológica, qualidade e produtividade; c) incentivo à produtividade agrícola; e d) consolidação e recuperação da infraestrutura.

Com vistas ao crescimento e à distribuição de renda: a) saneamento financeiro do Estado e estabilização da economia; b) incentivo à produção vinculada à incorporação de tecnologias modernas; c) estímulo seletivo ao investimento e à produção de bens de elevado efeito multiplicador sobre o emprego e a renda; e d) reforma agrária.

Voltadas à sustentabilidade do desenvolvimento: a) zoneamento ecológico-econômico para ordenação do território nacional; b) adequação de padrôes de produção e consumo de bens e serviços; c) implantação de um Sistema Nacional de Unidades de Conservação (que acabou ocorrendo em 2000, pela Lei n. 9.985/2000); e d) recuperação do meio ambiente, rural e urbano.

Com a finalidade de equalizar as oportunidades: a) ações articuladas de combate à pobreza; b) ação integrada para a criança e o adolescente; c) otimização dos serviços de seguridade social; e d) instrumentação e defesa da cidadania.

$\mathrm{Na}$ estratégia de modernização do Estado, foram as seguintes: a) continuidade da reforma administrativa e patrimonial com vistas à consolidação de um Estado moderno e eficiente (o que veio a ocorrer de forma mais evidente e intensa a partir da ação do Ministério da Administração Federal e Reforma do Estado (MARE)), em 1995; b) constitucionalidade e cidadania; c) consolidação das funções indelegáveis do Estado: defesa e relações exteriores; e d) articulação da ação pública, via planejamento moderno, com implantação de um Sistema Unificado de Planejamento, Orçamento e Gestão - interessante observar que isso ainda não se concretizou, não obstante seja de extrema relevância para o adequado funcionamento do sistema de planejamento, orçamento e gestão da administração pública.

O PPA 1991-1995, com sua complementação pela revisão para o período de 1993 a 1995, como primeira experiência de planejamento normativo de médio prazo nos termos fixados pelas normas introduzidas pela Constituição de 1988, mostrou, por um lado, um avanço no planejamento orçamentário governamental, representando verdadeira retomada da sua importância, após período em que foi pouco levado em consideração.

Contudo, por outro lado, como primeira experiência, conforme registrado, não foi bem-sucedido, pelas razões já apontadas, e, como registrou Ronaldo Garcia, também por não passar de "carta de intenções introdutória - sempre bastante generosa e audaciosa -, seguida de orçamento plurianual de investimentos e das 
demais despesas exigidas, sem nenhum nexo com as intenções anunciadas"63 (o que, como se verá, não obstante os aperfeiçoamentos que se seguiram, não se alterou significativamente, sendo ainda hoje procedente, ao menos em parte, a crítica).

Embora não se possa dizer que essa primeira experiência tenha alcançado os resultados esperados, especialmente em função da instabilidade política e econômica do período, que em muito dificultou a implementação de um planejamento preciso, há que se reconhecer um saldo positivo, pois, como se verá a seguir, passou a ser implementado e aperfeiçoado a cada nova edição, tanto no âmbito federal quanto nos demais entes da federação, em processo contínuo que se vê encontrar-se ainda em fase de busca de um modelo ideal e de uma regulamentação.

\subsubsection{O Plano Plurianual 1996-1999}

O ano de 1994, sob o governo do presidente Itamar Franco, foi marcado pela estabilização da moeda, com o advento do Plano Real, a substituição da moeda e a drástica redução do processo inflacionário.

Eleito no final do ano, tomou posse em 1995 o presidente Fernando Henrique Cardoso para exercer o mandato no período de 1995 a 1998, podendo, então, preparar um Plano Plurianual para o período de 1996 a 1999, já sob condiçōes econômicas mais favoráveis para um planejamento orçamentário governamental.

O PPA para o período de 1996 a 1999, Lei n. 9.276, de 9 de maio de 1996, elaborado para o primeiro período de mandato do presidente Fernando Henrique Cardoso, tinha uma diretriz fundamental e básica: a necessidade de consolidação e estabilização de preços, além de três estratégias a orientar a ação do Governo no período: a) a construção de um Estado moderno e eficiente; b) a redução dos desequilíbrios espaciais e sociais do País; e c) a modernização produtiva da economia brasileira (Anexo, item I).

Associadas a cada uma dessas estratégias, são estabelecidas várias diretrizes de ações do Governo (a estratégia "construção de um Estado moderno e eficiente", por exemplo, tem entre suas diretrizes, além de outras, a consolidação do processo de saneamento das finanças públicas e o aumento da eficiência do gasto público).

O PPA 1996-1999 é autointitulado com um “inconteste caráter social”, mas exibe como prioridades na alocação de recursos públicos o "investimento em infraestrutura econômica" e a "capacitação de recursos humanos". A canalização dos recursos também é priorizada para as regiōes econômicas mais frágeis.

63 GARCIA, Ronaldo Coutinho. PPA: o que não é e o que pode ser, p. 60. 
Fixaram-se objetivos e metas, para serem cumpridos de forma regionalizada, direcionando-se a alocação de recursos para as regiōes de bases econômicas mais frágeis (Anexo, item I.2), que se estruturam por áreas temáticas e por açóes e projetos, da seguinte forma (Anexo, item II): I) Infraestrutura econômica, subdivididas nas áreas de transporte, energia e comunicações; II) Recursos hídricos; III) Agricultura; IV) Indústria e comércio exterior; V) Turismo; VI) Ciência e tecnologia; VII) Meio ambiente; VIII) Desenvolvimento social, subdivididas nas áreas de previdência social, assistência social, saúde, educação, saneamento, habitação, desenvolvimento urbano e trabalho; IX) Cultura, justiça, segurança e cidadania; X) Estado e Administração Pública, em que o PPA também coloca como objetivo a intensificação de medidas do Governo "para melhorar a eficiência da gestão pública, capacitando a administração federal para formular e executar políticas governamentais em bases modernas e eficientes, revertendo a degradação dos serviços públicos básicos"; e XI) Defesa Nacional, área em que um dos objetivos é a "execução de pesquisas e desenvolvimento de projetos visando a nacionalização da produção de equipamentos e a obtenção de tecnologia de fabricação de materiais de emprego nas Forças Armadas", cabendo destacar nesse aspecto a Lei n. 12.598, surgida apenas em 2012 (22 de março), que estabeleceu normas especiais para as compras, as contrataçôes e o desenvolvimento de produtos e de sistemas de defesa.

No objetivo "Desenvolvimento social", merecem destaque as áreas da previdência social e da educação, sobre as quais cabem algumas considerações.

Vê-se claramente que os objetivos fixados no âmbito da previdência social vieram a se concretizar em reformas constitucionais ocorridas anos depois, posteriores até mesmo ao período do plano, consoante se pode constatar de alterações em redações de artigos constitucionais em decorrência, principalmente, das Emendas Constitucionais ns. 20, de 15 de dezembro de 1998, e 41, de 19 de dezembro de 2003.

No setor da educação, vários objetivos acabaram sendo acolhidos na Lei $\mathrm{n}$. 9.394, que veio a ser publicada em 20 de dezembro de 1996 para estabelecer as diretrizes e bases da educação nacional, que, além das disposições especificamente voltados à área educacional propriamente dita, trouxe disposições relevantes ao aspecto orçamentário, federativo e de planejamento, regulamentando divisões de atribuições entre os entes da federação, formas de financiamento e distribuição de recursos, programas e planejamento, com a referência expressa à incumbência da Uniāo na elaboração do Plano Nacional de Educação, que surgiu posteriormente, com a Lei n. 10.172, de 9 de janeiro de 2001.

O tema será tratado de maneira mais detalhada em capítulo próprio, destinado ao planejamento setorial no âmbito da educação, ficando aqui apenas este breve registro. 
Breve menção também merece ser feita ao setor de desenvolvimento urbano, em que um dos objetivos é o "aperfeiçoamento do marco jurídico-institucional para o desenvolvimento urbano no País, baseado na gestão descentralizada das açōos e na cooperação entre as três esferas de governo". E, na área da habitação, outro objetivo correlato é "a estruturação da legislação fundiária, propiciando a adequada regulação do uso e ocupação do solo urbano". São objetivos cuja concretização se tornou factível a partir do surgimento do Estatuto das Cidades, pela Lei n. 10.257, de 10 de julho de 2001.

No objetivo "Estado e Administração Pública", cabe destaque à Emenda Constitucional n. 19, de 4 de junho de 1998 - publicada, portanto, ainda no período do PPA -, que trouxe um grande impulso a esse objetivo, promovendo significativas alterações constitucionais no sentido de modernizar a Administração Pública, destacando-se, entre outros e principalmente, a introdução do princípio da eficiência no caput do art. 37.

Nessa área temática, está compreendida a preocupação com o planejamento, com objetivos fixados especificamente para "planejamento e administração pública", que são interessantes reproduzir.

Entre as medidas voltadas à administração pública, cuja preocupação com o aumento da eficiência é coerente com a reforma que se produzia à época, e sobre a qual já se fez referência anteriormente, foram estabelecidos os seguintes objetivos:

a) redefinição do papel e das competências do Estado para melhorar a alocação de recursos e o compartilhamento de suas responsabilidades com as demais esferas de governo;

b) promoção da descentralização das ações de governo a gestores governamentais e não governamentais;

c) concessão de maior autonomia às entidades da administração indireta, vinculada ao cumprimento de objetivos preestabelecidos;

d) reconstrução da administração pública em bases modernas e racionais, para elevar a eficiência na prestação de serviços à população;

e) fortalecimento institucional do setor público para o cumprimento das funções de concessão, regulação e fiscalização em áreas abertas à atuação do setor privado;

f) manutenção e adequação da infraestrutura física, inclusive informatização, necessária ao bom desempenho das funções de Estado, mediante ações dos Poderes Executivo, Legislativo e Judiciário;

g) capacitação sistemática de recursos humanos, com a criação de instrumentos de incentivo por mérito e eficiência do servidor. 
No que tange mais especificamente ao planejamento, destaca-se o objetivo "fortalecimento das atividades de planejamento, acompanhamento e avaliação das açōes governamentais, por meio do aprimoramento metodológico, da capacitação técnica e gerencial, da operacionalização de sistemas de informações e do tratamento adequado dessas informaçōes".

O PPA também coloca como objetivo a intensificação de medidas do Governo "para melhorar a eficiência da gestão pública, capacitando a administração federal para formular e executar políticas governamentais em bases modernas e eficientes, revertendo a degradação dos serviços públicos básicos”.

$\mathrm{Na}$ área fiscal e fazendária, um dos objetivos é a "modernização e aperfeiçoamento da gestão financeira federal, redefinindo e aprimorando os instrumentos de administração da dívida pública interna e externa”. Trata-se de medida que, como outras às quais se fará referência oportunamente, veio a ser implementada muitos anos depois, já sob a égide de outro PPA, como se vê nesse caso, em que a Emenda Constitucional n. 42, de 19 de dezembro de 2003, determinou que se desse tratamento prioritário às administrações tributárias (nova redação do art. 37, XXII), inclusive permitindo a vinculação de receitas de impostos quando destinados à realização de atividades da administração tributária (nova redação do art. 167, IV).

$\mathrm{Na}$ mesma área, outro objetivo é a "reestruturação do Sistema de Controle Interno, dotando o Poder Executivo de informações confiáveis sobre o andamento de ações, programas e projetos governamentais", o que, à semelhança do que foi mencionado no parágrafo anterior, veio a ocorrer com a Lei n. 10.080, de 6 de fevereiro de 2001, que organizou o sistema de planejamento orçamentário governamental, contabilidade e controle interno. A lei estabeleceu os órgãos envolvidos, as finalidades e as funções do sistema de planejamento, bem como da administração financeira, a contabilidade federal e o sistema de controle interno, este último com funções que cresceram no âmbito do planejamento, especialmente em razão de sua missão constitucional de avaliar o cumprimento das metas do PPA e os resultados, quanto à eficácia e à eficiência, da gestão orçamentária (Constituição, art. 74).

Em agosto de 1996, é lançado o Programa Brasil em Ação, que escolheu 42 empreendimentos em caráter prioritário do PPA 1996-1999, visando a incentivar investimentos em infraestrutura econômica e desenvolvimento social que pudessem melhorar a competitividade da economia, reduzir os desequilíbrios regionais, atrair investimentos privados e viabilizar as parcerias público-privadas. Deu-se início à implantação de um novo modelo de gestão pública, voltado a alcançar resultados por meio de um sistema de gerenciamento intensivo. As açóes governamentais passaram a ser organizadas sob a forma de projetos, com a designação de um 
gerente, estabelecendo-se objetivos e metas, com programação física e financeira, controle de custos, prazos e qualidade, tudo isso controlado por um sistema de informações gerenciais. ${ }^{64}$

O programa foi concluído em dezembro de 1999, ficando alguns dos projetos, cujas metas não foram atingidas, incluídos no PPA 2000-2003.

A análise do PPA 1996-1999 permite constatar com bastante clareza que foi elaborado com a natureza de um verdadeiro planejamento econômico governamental, estabelecendo diretrizes e objetivos muitas vezes de caráter nacional, amplos e abrangentes, que tiveram papel fundamental na indicação e orientação das importantes reformas constitucionais surgidas durante e mesmo após o período do plano, muitas delas sem necessariamente importarem em implicações de natureza orçamentária. Ronaldo Garcia segue nessa linha ao asseverar que

“o PPA 1996/1999, apesar de introduzido por um discurso mais ambicioso, não consegue ultrapassar a natureza última de um OPI. Quando busca fazê-lo, pela abrangência dos assuntos do texto de apresentação, não destaca ações, instrumentos de política, mecanismos de coordenação e atualização, sistemas de direção estratégica, entre outros, que pudessem conformar algo mais. Alcança, quando muito, o caráter de um plano econômico normativo de médio prazo". ${ }^{65}$

Os principais elementos que permitem reconhecê-lo como um planejamento orçamentário governamental vieram a aparecer no anexo com as tabelas, contendo a especificação, para cada área temática, das ações, objetivos e metas, de forma regionalizada, notando-se estarem construídas de maneira ainda incipiente em termos de técnicas de planejamento.

\subsubsection{O Plano Plurianual 2000-2003}

O Plano Plurianual para o período de 2000 a 2003 foi certamente o de maior relevância para o avanço do planejamento orçamentário governamental brasileiro, com uma mudança de paradigma na forma de elaboração dos PPA. Materializado na Lei Federal n. 9.989, de 21 de julho de 2000, foi o primeiro PPA implementado após a vigência da Lei de Responsabilidade Fiscal.

Teve, entre outros destaques, importância por intensificar a integração entre planejamento e programação orçamentária, inovando ao estabelecer o programa

64 BRASIL. Ministério do Planejamento, Orçamento e Gestão. Secretaria de Planejamento e Investimentos Estratégicos. O desafio do planejamento governamental, p. 16.

65 GARCIA, Ronaldo Coutinho. A reorganização do processo de planejamento do governo federal: o PPA 2000-2003, p. 26. 
como unidade básica de organização do PPA e consolidando a classificação funcional-programática nas três esferas de governo. Essa classificação passou a ser feita exclusivamente no nível da função e da subfunção, consideradas categorias para a análise de políticas. Teve o objetivo, também, de fazer com que os programas se referissem à solução de problemas precisamente delimitados, e cada programa passou a ser identificado por açôes, que se desdobram em projetos e atividades, além de operações especiais. ${ }^{66}$ A compatibilização entre o PPA e os orçamentos anuais importou em uma complexa e trabalhosa tarefa de revisão de todos os programas e ações orçamentárias, de modo a torná-los perfeitamente relacionados entre si, e os novos programas passaram a ser elaborados já nos formatos do PPA, ${ }^{67}$ importando inclusive em alteração nas estruturas dos Ministérios, para facilitar a implementação do PPA, de modo a induzir a administração a "suprimir as superposições e priorizar as ações finalísticas em detrimento das atividades-meio". ${ }^{68}$ O PPA 20002003 foi responsável "por reorganizar toda a ação do Estado em um modelo de integração entre plano, orçamento e gestão, que estabeleceu o programa de governo como unidade de gestão com foco em resultados", como destaca Luiz Fernando Paulo. ${ }^{69}$

Consolidou a utilização dos planos e orçamentos como instrumentos de uma administração pública "gerencial", voltados à busca de resultados, ${ }^{70}$ como fica claro na mensagem de encaminhamento:

"Como se sabe, os programas do Plano Plurianual - PPA deixaram de ser uma simples forma de classificação de gastos e passaram a ser um conjunto integrado de açôes que busca resultados. Cada ação deve ajustar-se nesse conjunto como uma peça importante, com finalidade específica e sempre identificada com as causas do problema ou

66 GARCIA, Ronaldo Coutinho. A reorganização do processo de planejamento do governo federal: o PPA 2000-2003, p. 61-62.

67 GARTENKRAUT, Michael. Fortalecimento da função avaliação nos países da América do Sul. Relatório técnico. Brasil: uma análise do Plano Plurianual 2000/2003, p. 58.

68 GARTENKRAUT, Michael. Fortalecimento da função avaliação nos países da América do Sul. Relatório técnico. Brasil: uma análise do Plano Plurianual 2000/2003, p. 62.

69 PAULO, Luiz Fernando Arantes. Plano plurianual. Teoria, prática e desafios para a sua efetividade, p. 17.

70 "A primary objective of the PPA 2000-2003 is to improve impact of government programs through a more results-oriented, 'managerial' public administration. Explaining why the government launched the new planning initiative, the Ministry of Planning web site emphasizes that 'the society wants public administration with results orientation, which translates into more food, employment, security, schools, hospitals, housing, water and sewage" (WORLD BANK. Brazil planning for performance in the federal government. Review of plurianual planning, p. 16). 
demanda que exigiu a criação do programa. Para que a execução - orçamentária, financeira ou física - de cada programa não dê margem a dúvidas, um dos requisitos é que não haja ações conflitantes entre si. É importante também que as ações sejam claras e objetivas, de modo a não gerar dúvidas quanto à sua finalidade, e não se transformem em rubricas que abriguem indiscriminadamente qualquer tipo de gasto".

Destaque-se, também, a referência à clareza dos programas, de modo a evitar os chamados "programas guarda-chuva", que, em face da sua pouca especificidade, permitem abranger quaisquer despesas, prejudicando a transparência dos gastos e o próprio planejamento. Fica clara, ainda, a organização das ações do governo federal com foco nas finalísticas, a estruturação dos programas e a adoção de modelo de gerenciamento orientada para a obtenção de resultados. ${ }^{71}$

Esse aperfeiçoamento na forma de elaboração e apresentação da proposta resultou de trabalho desenvolvido pelo Grupo de Trabalho Interministerial (GTI) em 1997, concretizando-se no Decreto n. 2.829, de 29 de outubro de 1998, que estabeleceu normas para a elaboração e a execução do Plano Plurianual e dos Orçamentos da União. ${ }^{72}$ Alguns dos conceitos trazidos no decreto foram aclarados na Portaria n. 117, de 12 de novembro de 1998, do Ministério do Planejamento, Orçamento e Gestão (MPOG), substituída em seguida pela Portaria n. 42, de 14 de abril de 1999, nas quais também se desdobrou a categoria das funções em subfunções. Nesses instrumentos normativos, estabeleceu-se que "toda ação finalística do Governo Federal deverá ser estruturada em Programas orientados para a consecução dos objetivos estratégicos definidos para o período do Plano (vigente de 2000 a 2003)" ${ }^{73}$ Além disso, previu-se que cada programa deveria conter objetivo, órgão responsável, valor global, prazo de conclusão, fonte de financiamento, indicador que quantifique a situação que o programa tem por objetivo modificar, as metas correspondentes aos bens e serviços necessários para atingir o objetivo, as ações não integrantes do Orçamento Geral da União necessárias para atingir o

71 GARTENKRAUT, Michael. Fortalecimento da função avaliação nos países da América do Sul. Relatório técnico. Brasil: uma análise do Plano Plurianual 2000/2003, p. 59.

72 Ronaldo Garcia destaca ainda que "o GTI, que concluiu seus trabalhos em dezembro de 1997 , buscou fazer do PPA um plano de governo e um instrumento viabilizador da integração dos objetivos estratégicos com o orçamento, mediante definições e conceituações das principais categorias do PPA, da LDO e do OGU (...) 3) Os programas passariam a ser integrados por açôes. Nos programas orçamentários, as ações foram desdobradas em objetivos e atividades e a cada um destes corresponderia um produto, com sua respectiva meta" ( $P P A$ : o que não é e o que pode ser, p. 61-62).

73 Art. 1º, Decreto n. 2.829/1998. Definiu-se "ação finalística" como "aquela que proporciona bem ou serviço para atendimento direto a demandas da sociedade” (idem, parágrafo único). 
objetivo e a regionalização das metas por Estado. Os programas caracterizados por açóes continuadas deveriam ter prazo definido para atingir metas quantitativas e de produtividade. Eliminaram-se, ademais, as categorias de classificação "subprograma", "subprojeto" e "subatividade".

Outra inovação que merece destaque foi na metodologia com que foi preparado, dando enfoque programático ao planejamento e aos orçamentos. A coordenação da elaboração do PPA 2000-2003 foi desempenhada tanto pela Secretaria de Planejamento e Avaliação (SPA) quanto pela Secretaria de Orçamento Federal (SOF). Como estratégia de implementação, foi necessário adotar programas de treinamento de servidores, para que se habilitassem a lidar com os novos conceitos de planejamento orçamentário (por exemplo, como operar adequadamente a categoria funcional-programática) e com o Sistema Integrado de Administração Financeira (SIAFI).

Nesse PPA, deu-se também ênfase à criação e ao aperfeiçoamento de mecanismos para a avaliação e o controle das ações, especialmente em função da necessidade de aferir os resultados, que passaram a ter especial relevância com a nova sistemática implantada.

O PPA 2000-2003 estabeleceu como diretrizes consolidar a estabilidade econômica com crescimento sustentado, promover o desenvolvimento com geração de emprego e oportunidades de renda, combater a pobreza e promover a cidadania e a inclusão social, além de consolidar a democracia e a defesa dos direitos humanos. Por iniciativa do Congresso, agregaram-se ainda, como diretrizes, a redução das desigualdades inter-regionais e a promoção dos direitos de minorias vítimas de preconceito e discriminação. Os 350 programas que dele constaram compuseram o assim chamado "Plano Avança Brasil".

Além das diretrizes fixadas, esse Plano Plurianual estabeleceu como objetivos o controle da inflação e a promoção do desenvolvimento, por meio de um ajuste fiscal rigoroso, com programas de aumento na arrecadação tributária, observância da Lei de Responsabilidade Fiscal, recém-promulgada, e a gestão integrada entre o PPA e os orçamentos, visando a uma maior compatibilidade entre receitas e despesas. Estabeleceu, ainda, a possibilidade de parcerias com o setor privado para os investimentos públicos.

Os eixos nacionais de desenvolvimento permitiram identificar e sistematizar os grandes problemas nacionais nas diversas áreas (energia, transportes, telecomunicações, desenvolvimento social, meio ambiente, informação e conhecimento), e, a partir deles, criarem-se os programas orçamentários e respectivas ações e projetos. Esses eixos serviram de referência para a organização espacial das ações e para a 
escolha de projetos aptos a modificar estruturas, que puderam lhe conferir a característica de um plano de desenvolvimento nacional. Destacaram, também, a possibilidade de "alavancar" a capacidade de investimentos, por meio da parceria com outros entes federativos, com o setor privado e organismos internacionais. ${ }^{74}$

\subsubsection{O Plano Plurianual 2004-2007}

O Plano Plurianual para o período de 2004 a 2007 foi instituído pela Lei n. $10.933 / 2004$, posteriormente alterada por leis que procederam à ajuste e à revisão do PPA para o restante do período (especialmente Leis ns. 11.044/2004, 1.318/2006 e $11.450 / 2007) .^{75}$

Esse plano não introduziu mudanças significativas na metodologia de elaboração adotada pelo PPA 2000-2003. Ao contrário, os conceitos, os fundamentos metodológicos, o modelo de gestão e a organização por programas foram mantidos. ${ }^{76}$ A inovação trazida pelo plano, entretanto, deu-se em outro setor: o da participação na definição dos programas, que serviu de mote para o nome fantasia "Brasil de Todos".

Primeiro plano apresentado sob o governo do presidente Luís Inácio Lula da Silva, o PPA 2004-2007 destaca a maior participação social nas escolhas das políticas públicas, buscando implantar "um novo padrão de relação entre o Estado e a sociedade, marcado pela transparência, solidariedade e corresponsabilidade". 77

A estratégia participativa foi colocada em prática por meio da realização de reuniōes técnicas envolvendo diversos órgãos governamentais e a sociedade civil, em fóruns de discussão. Essa experiência de debates deveria ocorrer não apenas na fase de elaboração, mas também de implementação do plano, nas etapas em que se processassem suas revisóes.

O PPA 2004-2007 é composto de quatro anexos: Anexo I - Orientação Estratégica do Governo; Anexo II - Programas de Governo; Anexo III - Órgão Responsável por Programas de Governo; e Anexo IV - Programas Sociais.

74 MARTINS, Humberto F. Avança Brasil e a gestão empreendedora: uma análise de modelos de planejamento e gestão governamental. Revista Eletrônica sobre a Reforma do Estado, p. 2.

75 O PPA previu, no bojo de seu texto, uma revisão a ser feita anualmente, nos termos do art. 50 e $\$ 1^{\circ}$, determinando que cada alteração ou exclusão seja feita por projeto de lei específico ou por meio de revisão anual, este último devendo ser encaminhado ao Congresso Nacional até o dia 31 de agosto dos exercícios de 2004, 2005 e 2006.

76 CALMON, Kátia Maria N.; GUSSO, Divonzir A. A experiência de avaliação do plano plurianual (PPA) do governo federal no Brasil. Planejamento e Políticas Públicas, p. 27.

77 Lei n. 10.933/2004, Anexo I, p. 4. 
A Orientação Estratégica de Governo, exposta no Anexo $I^{78}$ estrutura-se em três "Megaobjetivos", a saber:

- Megaobjetivo I - Inclusão social e redução das desigualdades sociais, que se desdobra em dez desafios.

- Megaobjetivo II - Crescimento com geração de trabalho, emprego e renda, ambientalmente sustentável e redutor das desigualdades sociais, consubstanciado em onze desafios.

- Megaobjetivo III - Promoção e expansão da cidadania e fortalecimento da democracia, que se concretizará por meio de nove desafios.

Por meio deles, pretende-se mudar o País e melhorar a vida dos brasileiros, enfrentando aqueles que são considerados os problemas fundamentais: "os problemas fundamentais a serem enfrentados são a concentração social e espacial da renda e da riqueza, a pobreza e a exclusão social, o desrespeito aos direitos fundamentais da cidadania, a degradação ambiental, a baixa criação de emprego e as barreiras para a transformação dos ganhos de produtividade em aumento de rendimentos da grande maioria das classes trabalhadoras". ${ }^{79}$

Esses megaobjetivos, desdobrados em desafios (anteriormente denominados "macro-objetivos"), acolheram algumas das sugestôes oriundas dos fóruns de discussão. A elaboração do plano contou, também, com a participação do recém-criado Conselho de Desenvolvimento Econômico e Social, composto por membros do governo e representantes da sociedade civil, sendo encaminhada a proposta elaborada pelo Presidente da República e pelo Ministério do Planejamento.

Em uma segunda fase do processo de elaboração, deveriam ser estabelecidas orientaçōes estratégicas setoriais. Nessa etapa, porém, não houve uma metodologia bem definida sobre como cada ministério deveria traçar tais orientaçôes. ${ }^{80}$ Assim, as propostas originais de cada órgão governamental foram bastante heterogêneas, mesmo devido à insuficiente capacitação técnica das equipes. A superposição de objetivos demonstrou, ainda, a falta de coordenação entre os diferentes órgãos.

A terceira fase de formulação do plano desdobrou-se em uma etapa quantitativa e em outra qualitativa. Nesta, os órgãos setoriais definiram os objetivos dos programas. Naquela, os montantes orçamentários necessários para o seu cumprimento.

\footnotetext{
78 Em que se destaca o aspecto participativo, tendo sido esse tipo de nova estratégia debatida na ENAP e com o Conselho de Desenvolvimento Econômico e Social - CDES, além dos Fóruns da Participação Social nos Estados e Distrito Federal.

79 Lei n. 10.933/2004, Anexo I, p. 6.

80 CALMON e GUZZO, A experiência..., p. 29.
} 
Construiu-se uma Estratégia de Desenvolvimento de Longo Prazo, exposta a partir desse PPA, que busca a

"inclusão social e desconcentração de renda com vigoroso crescimento do produto e do emprego; crescimento ambientalmente sustentável, redutor das disparidades regionais, dinamizado pelo mercado de consumo de massa, por investimentos, e por elevação da produtividade; redução da vulnerabilidade externa por meio da expansão das atividades competitivas que viabilizam esse crescimento sustentado; e fortalecimento da cidadania e da democracia”. ${ }^{81}$

E reconhece a importância do planejamento e o papel do PPA para o sucesso desse processo:

"Não se faz uma mudança desse porte sem planejamento. O Plano Plurianual (PPA) 2004-2007 (Plano Brasil de Todos) foi construído para mudar o Brasil. Inaugura um modelo de desenvolvimento de longo prazo, para muito além de 2007, destinado a promover profundas transformações estruturais na sociedade brasileira. É a peça-chave do planejamento social e econômico do Governo do Presidente Luiz Inácio Lula da Silva. O PPA confere racionalidade e eficácia às ações do Governo Federal na direção dessas profundas mudanças" ${ }^{82}$

Destaca e ressalta o papel do Estado nessa missão, reconhecendo as falhas ainda presentes no sistema de planejamento governamental:

"Para implantar esse projeto de desenvolvimento é preciso que o Estado tenha um papel decisivo, como condutor do desenvolvimento social e regional e como indutor do crescimento econômico. A ausência de um projeto de desenvolvimento resultou na falta de foco dos Planos Plurianuais precedentes. Na esfera social, por exemplo, acumularam-se programas superpostos, com poucos resultados práticos. É preciso uma virada total na forma de planejar. Dadas as características atuais do Estado, da sociedade e do sistema produtivo brasileiros, a atividade de planejamento deve ser compreendida como coordenação e articulação dos interesses públicos e privados no sentido de minorar a pobreza da população, minimizar as desigualdades sociais e regionais, redistribuir renda, reduzir o desemprego, superar a escassez de financiamento, reduzir incertezas e elevar o investimento público e privado”.

E mostra que o planejamento estratégico das ações de governo tem papel fundamental para compatibilizar os objetivos a alcançar os melhores resultados. ${ }^{83}$

Outro traço distintivo do PPA 2004-2007 foi a criação de um Sistema de Monitoramento e Avaliação do Plano Plurianual. ${ }^{84}$ O Sistema de Informações Ge-

81 Lei n. 10.933/2004, Anexo I, p. 7.

82 Lei n. 10.933/2004, Anexo I, p. 6.

83 Lei n. 10.933/2004, Anexo I, p. 7.

$84 \mathrm{O}$ art. 9º , com redação dada pela Lei n. 11.318/2006, prevê caber ao Poder Executivo enviar ao Congresso Nacional, até o dia 15 de setembro de cada ano, o relatório de avaliação do Plano. 
renciais e de Planejamento do Plano Plurianual (SIGPlan) permite a integração entre as pessoas responsáveis pela elaboração, pelo monitoramento, pela avaliação e pela revisão dos programas do PPA, possibilitando um melhor gerenciamento do andamento dos programas. Os aspectos gerenciais que caracterizaram o Plano Avança Brasil se manifestaram, aí, como a origem de uma preocupação com os resultados obtidos em núcleos programáticos de atuação. $\mathrm{O}$ referido sistema teve o fim de aperfeiçoar a transparência às ações do governo (por meio de informações sobre o desempenho dos programas executados) e auxiliar a tomada de decisão (trazendo informações úteis à melhoria progressiva dos programas do plano).

A avaliação do plano passou a contar, também, com uma Unidade de Monitoramento e Avaliação (UMA), à qual coube verificar e consolidar as avaliações dos gerentes dos programas.

Não obstante as inovações que colaboraram para o aperfeiçoamento da elaboração e, principalmente, monitoramento e avaliação do plano, vê-se ainda ser o sistema incipiente, registrando-se falhas no processo. O relatório de auditoria emitido pela Secretaria de Macroavaliação Governamental (SEMAG), órgão vinculado ao TCU, destacou o problema da pouca precisão na formulação das estratégias de governo e dos objetivos dos programas. Outro ponto levantado é que a maioria dos programas acaba não apresentando os indicadores - ou seja, parâmetros para o controle do desempenho - mínimos para aferir a execução do plano. Um terceiro ponto foi a confusão entre a apresentação dos problemas e das causas. ${ }^{85}$

No período do PPA 2004-2007, veem-se evidências claras - que depois se confirmam por outras, como se verá -, de falta de atenção e empenho dos governantes com o PPA como instrumento de planejamento, o que é um dos principais motivos de sua pouca efetividade. Ronaldo Garcia observa com propriedade a substituição do PPA por outros instrumentos de planejamento (alguns se mostram, inclusive, juridicamente mais frágeis, como também será objeto de análise oportunamente), mitigando a importância do PPA:

"Em 2004, ocorreram as metas presidenciais, um conjunto de programas e açóes se-
lecionados entre todos os listados no PPA, segundo importância a estes atribuída pela
Presidência da República. Em janeiro de 2007, ano de elaboração do plano (referin-
do-se ao PPA 2008-2011), o Programa de Aceleração do Crescimento (PAC) é anun-
ciado ao país, indicando os projetos prioritários para o desenvolvimento nacional. Em
abril de 2007, tem início a construção da Agenda Social em processo coordenado pela
Casa Civil, que ocorreu em paralelo à elaboração do PPA 2008-2011. Mais ou menos

85 BAPTISTA, Renata Ribeiro. TCU - Proc. 015271/2003-4. Controle do Plano Plurianual 2004/2007 pelo Tribunal de Contas da União. Revista de Direito do Estado, p. 361-362. 
nessa época, o Ministério da Educação (MEC) estava aprontando o Plano de Desenvolvimento da Educação, também de forma dissociada da montagem do PPA. O MP teve de ser criativo para incorporar nominalmente as três iniciativas na mensagem que encaminhava o PPA ao Congresso Nacional. São evidências fortes de que o PPA, por não ser seletivo e ser construído sem dar destaque às prioridades do governo, não consegue anunciar os objetivos maiores de cada governante. Com isso, deixa de atrair a atenção da alta direção para sua concepção e sua organização, reduzindo-se ao mero cumprimento de disposição constitucional, ainda não regulamentada e não situada no mais amplo processo de planejamento do desenvolvimento nacional" ${ }^{86}$

\subsubsection{O Plano Plurianual 2008-2011}

A Lei Federal n. 11.653, de 7 de abril de $2008,{ }^{87}$ instituiu o Plano Plurianual para o período de 2008 a 2011, que apresenta como objetivo responder ao "desafio de acelerar o crescimento econômico, promover a inclusão social e reduzir as desigualdades regionais". ${ }^{88}$

Tem apenas três anexos: Anexo I - Programas Finalísticos; Anexo II - Programas de Apoio às Políticas Públicas e Áreas Especiais; Anexo III - Órgãos Responsáveis por Programas de Governo. Os programas destinados a operações especiais foram excluídos do PPA.

Organizou as ações do governo em três grandes eixos: crescimento econômico, agenda social e educação de qualidade, a serem promovidos por meio de três agendas prioritárias, que justificam a denominação que lhes foi conferida, "Desenvolvimento com inclusão social e educação de qualidade": o Plano de Aceleração do Crescimento (PAC); a Agenda Social; e o Plano de Desenvolvimento da Educação (PDE), destacando como prioritários, com precedência sobre as demais ações governamentais, as que integrem o Plano Piloto de Investimentos (PPI) e o PAC.

O PAC, lançado em janeiro de 2007, constitui-se de um conjunto de obras estratégicas para superar gargalos no desenvolvimento do país e promover o desenvolvimento econômico, priorizando investimentos em várias áreas, como infraestrutura, especialmente nos setores de transporte, energia, saneamento e recursos hídricos, entre outros, partindo da constatação de que os investimentos para tanto são necessários. ${ }^{89}$ A Seção III (Lei n. 11.653/2008, arts. 11 a 14) é inteiramente

86 GARCIA, Ronaldo Coutinho. PPA: o que não é e o que pode ser, p. 443.

87 Posteriormente parcialmente atualizada pela Lei n. 12.352, de 2009.

88 BRASIL. Ministério do Planejamento, Orçamento e Gestão. Secretaria de Planejamento e Investimentos Estratégicos. Plano Plurianual 2008-2011, p. 9.

89 O PAC será objeto de análise específica em item próprio. 
dedicada ao PAC, o que demonstra a importância desse plano para o planejamento governamental orçamentário. $\mathrm{O}$ art. 11 define que "as ações do Programa de Aceleração do Crescimento - PAC constantes do Plano Plurianual 2008-2011 integram as prioridades da Administração Pública Federal, e terão tratamento diferenciado durante o período de execução do Plano, na forma do disposto nesta Lei”, estabelecendo medidas como a autorização para que sejam suplementadas por decreto, até o limite de $30 \%$, dotações consignadas nas ações do programa. ${ }^{90}$

A Agenda Social, que compreende "um conjunto de iniciativas prioritárias para ampliar oportunidades à parcela mais vulnerável da população, mediante uma política garantidora de direitos, a ser efetivada com gestão integrada e pactuação federativa entre União, estados e municípios" a seu turno, congregou, na área de educação, ações consideradas prioritárias para os mais necessitados, com ênfase nas transferências condicionadas de renda associadas às ações complementares, no fortalecimento da cidadania e dos direitos humanos, na cultura e na segurança pública. ${ }^{91}$

Por fim, o PDE, que também integra a Agenda Social, lançado anteriormente ao próprio PPA, e que reúne "um conjunto de iniciativas articuladas sob uma abordagem do sistema educativo nacional, cuja prioridade é a melhoria da qualidade da educação básica", ${ }^{92}$ capaz de formar indivíduos que possam assumir posturas críticas e criativas, mediante sistemas educacionais que estejam adequados às peculiaridades regionais e sejam voltados ao desenvolvimento econômico e social, "garantindo a todos e a cada um o direito de aprender até onde o permitam suas aptidões e vontade". 93

A agenda de prioridades prevista no PAC, na Agenda Social e no PDE se desdobrou em dez objetivos do governo: inclusão social e redução das desigualdades; crescimento econômico ambientalmente sustentável, com geração de empregos e distribuição de renda; acesso à educação e ao conhecimento com equidade, qualidade e valorização da diversidade; fortalecimento da democracia, com igualdade de gênero, raça e etnia e a cidadania com transparência, diálogo social e garantia dos direitos humanos; implantação de infraestrutura eficiente e integradora do território nacional; redução das desigualdades regionais a partir das potencialidades

Lei n. 11.653/2008, art. 12.

91 BRASIL. Ministério do Planejamento, Orçamento e Gestão. Secretaria de Planejamento e Investimentos Estratégicos. Plano Plurianual 2008-2011, p. 10 e 13.

92 BRASIL. Ministério do Planejamento, Orçamento e Gestão. Secretaria de Planejamento e Investimentos Estratégicos. Plano Plurianual 2008-2011, p. 16.

93 BRASIL. Ministério da Educação. O Plano de Desenvolvimento da Educação (PDE). Razões, princípios e programas, p. 6. 
locais; fortalecimento da inserção soberana internacional e integração sul-americana; elevação da competitividade sistêmica da economia, com inovação tecnológica; promoção de um ambiente social pacífico e garantia da integração dos cidadãos; e promoção do acesso com qualidade à seguridade social.

Os programas na área da saúde apresentaram algumas mudanças importantes. O número de programas da saúde passou por uma redução significativa com relação ao PPA 2004-2007: de 24 para 13. Tratou-se de um esforço para reorganizar os planos de investimentos e as prioridades do Ministério da Saúde. Entre o conjunto de iniciativas na área, é importante também dar destaque ao Sistema de Planejamento do Sistema Único da Saúde (PlanejaSUS), cujo objetivo é coordenar o processo de planejamento do Sistema Único de Saúde (SUS) nas três esferas de governo, sobre o qual se falará oportunamente, em item específico. Como a maior parte dos programas da saúde envolve decisões descentralizadas, é uma medida importante para sua coordenação.

Já no que tange às políticas de trabalho e renda, não houve muitas alterações. Os programas do Ministério do Trabalho e Emprego (MTE) têm se mostrado bastante estáveis ao longo do tempo, e a única alteração de alguma importância foi a exclusão do programa Primeiro Emprego, cujas ações estão abrigadas, hoje, no Programa Nacional de Inclusão de Jovens (ProJovem), sob responsabilidade da Secretaria Nacional de Juventude. A despeito dessa estabilidade, há duas iniciativas de pouca transparência que tomam boa parte dos recursos do MTE. A primeira delas é a definição de linhas de crédito por meio do Fundo de Amparo ao Trabalhador (FAT), que, por compor-se de recursos extraorçamentários, faz parte do PPA, mas não da lei de orçamento. A outra é a atuação normativa do MTE, em que apenas o custeio dos Fóruns Nacionais do Trabalho consta do plano. ${ }^{94}$

Releva destacar a especial referência à gestão do Plano Plurianual para o período de 2008 a 2011, que mereceu todo um capítulo (capítulo II, arts. 7o a 21), incluindo em seu texto a observância dos princípios da Administração Pública da eficiência (que tem estatura constitucional no art. 37), eficácia e efetividade (Lei n. $11.653 / 2008$, art. $7^{\circ}$ ), mediante processo de gestão que abrange sistemas de implementação, monitoramento, avaliação e revisão.

Manteve o sistema de revisões anuais, a serem propostas pelo Poder Executivo por meio de projetos de lei específicos, quando necessário (Lei n. 11.653/2008, art. 15), autorizando a inclusão de ações orçamentárias de caráter plurianual por meio de

94 BRASIL. Secretaria de Assuntos Estratégicos. IPEA - Instituto de Pesquisa Econômica Aplicada. Políticas sociais: acompanhamento e análise, p. 12-14. 
leis prevendo a abertura de créditos especiais, exigindo para tanto a apresentação das informações referentes às projeções plurianuais (Lei n. 11.653/2008, art. 15, $\$ 5^{\circ}$ ).

Normas complementares para a gestão do plano foram estabelecidas no Decreto n. 6.601, de 10 de outubro de 2008, estabelecendo que a gestão do PPA 20082011 orientar-se-á para resultados e será composta de dois níveis: o estratégico e o tático-operacional. O nível estratégico compreende os objetivos de governo e os objetivos setoriais, e o tático-operacional, os programas e as ações. A gestão do plano, coordenada pelo Ministério do Planejamento, Orçamento e Gestão, far-se-á, no nível estratégico, por meio do Comitê de Gestão do PPA, da Secretaria-Executiva, da Comissão de Monitoramento e Avaliação do Plano Plurianual (CMA) e das Unidades de Monitoramento e Avaliação (UMA); e no nível tático-operacional, pelos Gerentes de Programa, Gerentes-Executivos de Programa, Coordenadores de Ação, e Coordenadores Executivos de Ação.

Um aspecto de grande relevância em relação ao PPA 2008-2011 foi destacado pelo Tribunal de Contas da União, por ocasião do acompanhamento realizado nos procedimentos de elaboração do referido PPA, que constam do Acórdão 102/2009. Trata-se das dificuldades relacionadas com a cultura da administração pública, que ainda não se mostra adaptada a um novo modelo de gestão voltado a resultados. Uma questão recorrente, presente até os dias de hoje, e não resolvida. O TCU constatou ter o PPA 2008-2011 mantido o modelo de orçamento por resultados vigente nos PPA anteriores, com o programa sendo elemento de integração entre o planejamento e o orçamento, voltados a resolver um problema. ${ }^{95}$ Observa, contudo, após investigações em órgãos da administração pública federal, que, embora o modelo de gestão dê ênfase ao desempenho, "a sua institucionalização não veio precedida de uma mudança na estrutura da administração pública, quer dizer, não existe ainda uma responsabilização por resultados", ${ }^{96}$ e, não obstante os esforços que têm sido feitos para promover o envolvimento dos gestores e servidores com os resultados dos programas governamentais, isso não tem surtido o efeito desejado, o que é fundamental, pois "a incorporação do modelo de orçamento por resultados exige uma mudança cultural em uma estrutura organizacional ainda enraizada de viés burocrático". Identifica a dificuldade na elaboração de indicadores de boa qualidade, pela falta de proximidade dos gestores com as metodologias de elaboração dos programas, e a falta de comprometimento dos órgãos com os indicadores formulados

95 BRASIL. Tribunal de Contas da União. Acórdão 102/2009 - TCU - Plenário, Rel. Min. Augusto Nardes, sessão de 4.2.2009, p. 4.

96 BRASIL. Tribunal de Contas da União. Acórdão 102/2009, p. 6. 
para o PPA, que veem como formalidade burocrática a ser cumprida.${ }^{97}$ O Relator Min. Augusto Nardes, em seu voto, destaca a importância do PPA como instrumento de planejamento e gestão, considerando-o "peça política máxima”, que deve dar "corpo às plataformas apresentadas pelo Presidente da República durante a campanha eleitoral", ressaltando que devem ser criadas as condiçôes para que "a administração pública avance na moderna gestão por resultados”, por meio de um adequado planejamento, ressalvando a necessidade de aperfeiçoamento da adequação dos indicadores dos programas. ${ }^{98} \mathrm{O}$ Min. Aroldo Cedraz, em declaração de voto, segue na mesma linha, afirmando ter "a firme convicção de que um dos grandes desafios da administração pública brasileira é o aprimoramento da gestão, que passa, necessariamente, pelo desenvolvimento de uma sistemática de planejamento eficiente, eficaz e efetiva", e que os progressos do sistema de planejamento se mostraram bastante auspiciosos, e possibilitarão a melhoria do desempenho da administração pública, com uma gestão mais eficiente dos recursos e viabilizarão a responsabilização social dos gestores. ${ }^{99}$

Vê-se, portanto, haver uma preocupação e um avanço significativos no sentido de aperfeiçoamento do planejamento segundo as mais modernas técnicas de gestão pública, representando um passo importante, que tem se aperfeiçoado, ainda que não se verifique efetivamente, na realidade, uma efetiva concretização dessas medidas, especialmente em razão de uma cultura não incorporada de um novo modelo de gestão, nem a adoção integral do modelo pelos demais entes da federação.

\subsubsection{O Plano Plurianual 2012-2015}

Na Lei n. 12.593/2012, que instituiu o PPA 2012-2015, nota-se o reconhecimento formal do planejamento governamental como um processo mais amplo, do qual o PPA é um instrumento: "O planejamento governamental é atividade que, a partir de diagnósticos e estudos prospectivos, orienta as escolhas de políticas públicas" (art. 2o), sendo o PPA 2012-2015 o "instrumento de planejamento governamental que define diretrizes, objetivos e metas com o propósito de viabilizar a implementação e a gestão de políticas públicas, orientar a definição de prioridades e auxiliar na promoção do desenvolvimento sustentável" (art. 3º).

O PPA 2012-2015 trouxe algumas alterações importantes em relação aos planos anteriormente aprovados. Os instrumentos de planejamento orçamentário da

\footnotetext{
97 BRASIL. Tribunal de Contas da União. Acórdão 102/2009, p. 26.

98 BRASIL. Tribunal de Contas da Uniāo. Acórdão 102/2009, p. 29-30.

99 BRASIL. Tribunal de Contas da União. Acórdão 102/2009, p. 31.
} 
ação governamental foram reformulados em alguns aspectos essenciais para a compreensão da formulação dos planos plurianuais.

Destaque cabe à adoção de um caráter mais estratégico para o plano. Isso resultou em uma reorganização do Plano Plurianual no qual os instrumentos "programa" e "ação", centrais para a articulação entre o PPA e a lei orçamentária, foram substituídos por "programas temáticos", “objetivos" e "iniciativas"; a "ação" foi excluída dos planos plurianuais e se tornou um elemento de organização exclusivo dos orçamentos anuais. A “iniciativa” passa a fazer o papel de integração entre o plano e o orçamento. Com isso, critica Luiz Fernando Paulo, "o programa perde o escopo de organizar a gestão, tornando-se apenas um agregador de diversos objetivos reunidos sob um determinado tema". ${ }^{100}$

O PPA 2012-2015 foi elaborado a partir de uma estrutura em três dimensões: estratégica; tática; e operacional. A dimensão estratégica corresponde "a orientação estratégica que tem como base os Macrodesafios e a visão de longo prazo do Governo Federal”; a dimensão tática "define caminhos exequíveis para o alcance dos objetivos e das transformações definidas na dimensão estratégica, considerando as variáveis inerentes à política pública tratada", vinculando "os Programas Temáticos para consecução dos Objetivos assumidos, estes materializados pelas Iniciativas expressas no Plano"; e a dimensão operacional "relaciona-se com o desempenho da ação governamental no nível da eficiência e é especialmente tratada no Orçamento", buscando "a otimização na aplicação dos recursos disponíveis e a qualidade dos produtos entregues” ${ }^{101}$ Estabeleceu-se a competência do PPA para responder pelos níveis estratégico e tático do planejamento orçamentário, fazendo do orçamento anual o principal instrumento da dimensão operacional do plano.

Os "Macrodesafios" (dimensão estratégica, com foco na efetividade) são "diretrizes elaboradas com base no Programa de Governo e na Visão Estratégica”. O "Programa Temático" (dimensão estratégica, com foco na efetividade) espelha a agenda do governo em cada um dos temas de políticas públicas, e "sua abrangência deve ser a necessária para representar os desafios e organizar a gestão, o monitoramento, a avaliação, as transversalidades, as multissetorialidades e a territorialidade". Cada "Programa Temático" se desdobra em "Iniciativas e Objetivos". O "Objetivo" (dimensão tática, com foco na eficácia) expressa "o que deve ser feito, refletindo as situações que devem ser alteradas pela implementação de um conjunto

100 PAULO, Luiz Fernando Arantes. Plano plurianual. Teoria, prática e desafios para a sua efetividade, p. 52.

101 BRASIL. Ministério do Planejamento, Orçamento e Gestão. Secretaria de Planejamento e Investimentos Estratégicos. Orientaçôes para elaboração do Plano Plurianual 2012-2015, p. 10. 
de Iniciativas". A “Iniciativa” (dimensão operacional, com foco na eficiência), por sua vez, "declara as entregas à sociedade de bens e serviços, resultantes da coordenação de ações orçamentárias", além de outras ações. Finalmente, os "Programas de Gestão, Manutenção e Serviços ao Estado" são instrumentos que "classificam um conjunto de ações destinadas ao apoio, à gestão e à manutenção da atuação governamental, bem como as açóes não tratadas nos Programas Temáticos por meio de suas iniciativas". 102

É importante destacar que a cada "Macrodesafio" deve corresponder um "Programa Temático", cuja elaboração precisa seguir a lógica de organização da atuação do governo federal. Da mesma forma, a agregação de "Iniciativas" em torno a "Objetivos" se articula por meio dos "Programas Temáticos", com a finalidade de aprimorar a coordenação das ações de governo.

Como exemplos de "Programas Temáticos", temos "Energia Elétrica", "Agricultura Irrigada" e "Aperfeiçoamento do Sistema Único de Saúde (SUS)" - áreas que expressam desafios governamentais e agregam, com reflexos também em outros programas, ações consideradas determinantes para o desenvolvimento.

Os "Objetivos" procuram trazer soluções para situações que devem ser alteradas em cada "Programa Temático", expressando um resultado transformador da situação atual. A orientação tática, a definição de escolhas e a exequibilidade dos resultados devem ser suas características essenciais. Exemplos de "Objetivos" seriam: "aproveitamento do potencial de geração de energia elétrica a partir da fonte hídrica, de forma a ofertar grande quantidade de energia elétrica a baixos preços" (para o Programa Temático "Energia Elétrica"); "promoção de políticas de pesquisa, desenvolvimento e inovação para agricultura irrigada e difusão da tecnologia, por intermédio de uma rede formada pelas instituiçôes de pesquisa, assistência técnica e extensão rural, para otimização do uso do solo e da água e aumento da produtividade" (para o Programa Temático "Agricultura Irrigada”); e "expansão e qualificação da Rede de Urgências e Emergências, induzindo a cobertura de vazios assistenciais, com apoio à implantação e manutenção das Unidades de Pronto Atendimento (UPA), das Salas de Estabilização e do Serviço de Atendimento Móvel de Urgência (SAMU 192)" (para o Programa Temático "Aperfeiçoamento do SUS"). ${ }^{103}$

102 BRASIL. Ministério do Planejamento, Orçamento e Gestão. Secretaria de Planejamento e Investimentos Estratégicos. Orientaçôes para elaboração do Plano Plurianual 2012-2015, p. 11.

103 BRASIL. Ministério do Planejamento, Orçamento e Gestão. Secretaria de Planejamento e Investimentos Estratégicos. Orientaçôes para elaboração do Plano Plurianual 2012-2015, p. 22. 
A "Iniciativa" atua como instrumento de articulação entre o plano e o orçamento, pois as ações orçamentárias, sob o PPA 2012-2015, são criadas a partir daquelas. A cada "Iniciativa" podem corresponder uma ou mais açôes orçamentárias. Para o Programa Temático "Energia Elétrica", no Objetivo exposto anteriormente, algumas iniciativas poderiam ser, exemplificativamente, a "Implantação de Usinas Hidrelétricas", "Implantação de Pequenas Centrais Elétricas" etc. ${ }^{104}$

Entendeu-se que, com essa reorganização, as categorias adotadas no PPA se tornariam menos rígidas, com mais versatilidade e flexibilidade para a estruturação orçamentária de políticas públicas, podendo-se explicitar, com maior clareza, a identificação, a priorização e a seleção de beneficiários, bem como melhor organizar as relaçõos entre os entes federados e entre as esferas pública e privada. Da mesma maneira, procurou-se estabelecer condições para melhor tratamento da multissetorialidade de diversas políticas. Uma alteração que não se mostrou de todo adequada, tendo sido objeto de severas críticas pelos especialistas de forma geral, como se verá em seguida, principalmente por entenderem que, ao contrário do propagado, houve perda de clareza, tornando as prioridades vagas, o que causa dificuldades tanto na implantação e execução quanto no controle e na transparência.

O PPA 2012-2015 estrutura-se em torno de alguns princípios: participação social; incorporação de informações territoriais para orientar a alocação de investimentos; valorização do conhecimento sobre políticas públicas para a elaboração de programas temáticos; foco na execução dessas políticas; parcerias com estados, municípios, iniciativa privada e sociedade civil; foco na efetividade e na eficácia; e aperfeiçoamento das diretrizes para a alocação orçamentária mais eficiente.

A mensagem presidencial que encaminhou o "Plano Mais Brasil - Mais Desenvolvimento, Mais Igualdade, Mais Participação", em sua dimensão estratégica para o período, prevê o aproveitamento das potencialidades do país com a finalidade de alcançar um desenvolvimento sustentável, centrado em progresso técnico, e a redução das desigualdades, com inclusão social.

Paralelamente, o Ministério do Desenvolvimento Social e Combate à Fome, com o "Plano Brasil sem miséria" ${ }^{105}$ tem por foco acabar com a miséria, reduzindo as desigualdades, por meio de vários programas voltados a "promover a inclusão social e produtiva da população extremamente pobre, tornando residual o percentual dos que vivem abaixo da linha de pobreza”, objetivando elevar a renda familiar

104 BRASIL. Ministério do Planejamento, Orçamento e Gestão. Secretaria de Planejamento e Investimentos Estratégicos. Orientaçôes para elaboração do Plano Plurianual 2012-2015, p. 26.

105 Será objeto de análise em item próprio. 
per capita, ampliar o acesso aos serviços públicos, às ações de cidadania e de bem-estar social e às oportunidades de ocupação e renda por meio de açóes inclusivas. ${ }^{106}$

O Plano de Aceleração do Crescimento (PAC), por sua vez, busca atingir os demais objetivos estratégicos, visando a intensificar investimentos em infraestrutura de diversas áreas fundamentais para a promoção do desenvolvimento econômico sustentável.

O PPA 2012-2015 estabeleceu nove diretrizes (art. 40), com destaque para alguns itens, como os que visam "a garantia dos direitos humanos com redução das desigualdades sociais, regionais, étnico-raciais e de gênero", e "a ampliação da participação social", a "excelência da gestão", o "aumento da eficiência dos gastos públicos" e "o crescimento econômico sustentável", o que justifica ter destacado como prioridades o Plano Brasil Sem Miséria (PBSM) e o Programa de Aceleração do Crescimento (PAC).

No âmbito de sua dimensão tática, foram definidos 25 programas temáticos, que representam políticas sociais, de infraestrutura, de desenvolvimento produtivo e ambiental e políticas e temas especiais, com os quais se pretende alcançar os objetivos definidos como estratégia de governo.

Houve diminuição no número de programas, com a intenção de deixar mais claras e fáceis de compreender as prioridades, o que, no entanto, não atingiu o resultado pretendido, pois a alteração promovida acabou por não diminuir o detalhamento, não tendo colaborado para facilitar o entendimento, como bem observado pelo TCU. ${ }^{107}$

No que tange à gestão do plano, aos princípios da eficiência, eficácia e efetividade foi acrescentada a necessidade de observância dos princípios da publicidade e da impessoalidade (Lei n. 12.593/2012, art. 13), e vê-se que as atividades de implementação, monitoramento, avaliação e revisão passaram a ter maior transparência, especialmente em função dos sistemas informatizados acessíveis pela internet utilizados para a sua gestão.

O Poder Executivo tem à disposição para acompanhar a execução do PPA o Sistema Integrado de Planejamento e Orçamento do Governo Federal (SIOP), que

106 BRASIL. Ministério do Desenvolvimento Social e Combate à Fome. Plano Brasil Sem Miséria, p. 5-6.

107 Houve diminuição do número de programas, mas, com a criação de mais dois níveis de agregação de despesa (objetivos e iniciativas), acabou não ocorrendo a pretendida diminuição do detalhamento, tampouco melhora em seu entendimento por parte da sociedade ou maior clareza de seu conteúdo (2008-2011: 321 programas; 2012-2015: 65 programas temáticos e 44 programas de gestão, 492 objetivos, 2.417 metas, 2.503 iniciativas)" (BRASIL, TCU, Acórdão 1.012/2013, p. 8, item 55). 
integrou em um único sistema informatizado o Sistema Integrado de Dados Orçamentários (SIDOR), o Sistema de Informações Gerenciais e de Planejamento (SIGPlan) e o Sistema de Informação das Estatais (SIEST), sendo este último responsável pelas informações relacionadas com o orçamento de investimento das empresas estatais. ${ }^{108}$

A elaboração e a execução do PPA 2012-2015, em função das modificações na forma de estruturação dos programas, exigiram adaptaçōes para se adequarem à nova sistemática, o que evidentemente causa algumas dificuldades, como inclusive já registra o TCU, ${ }^{109}$ sendo necessário superá-las a fim de que se possa constatar a eficácia dessa nova experiência em planejamento orçamentário governamental.

Não obstante as tentativas de aperfeiçoamento, nem todas as alteraçōes foram bem recebidas, e permanecem algumas falhas já observadas em versões anteriores.

É o caso, por exemplo, da imperfeição nos indicadores, problema recorrente e persistente, que, como anteriormente mencionado, envolve inclusive a dificuldade em implementar uma nova cultura de gestores e servidores em adaptar-se e integrar-se a essa já não tão nova metodologia de planejamento e gestão.

O Tribunal de Contas da União, no Relatório sobre as Contas do Governo referentes ao exercício de 2014, observa essas fragilidades:

"Contudo, deve-se destacar que o modelo vigente de PPA apresenta fragilidades, como têm asseverado atores relevantes, incluindo consultorias legislativas no âmbito do Congresso Nacional e o próprio TCU. Há uma forte preocupação, por exemplo, com a criação de programas temáticos, cuja concepção não permite evidenciar a lógica das intervençôes governamentais para alcançar objetivos e atender a demandas sociais. Em relação às características dos atributos, também têm sido apontados problemas em relação aos indicadores - que não guardam, em parte significativa dos casos, relação mais direta com os objetivos de cada programa - e com a atribuição de metas apenas para o período total do plano, sem especificar as entregas associadas a cada exercício - ao passo que os recursos são anualizados para o primeiro ano pendente de execução. Entre outras, essas fragilidades reduzem a transparência do plano e

108 BRASIL. Tribunal de Contas da União. Relatório e parecer prévio sobre as contas do Governo da República. Exercício 2012, p. 247.

109 "O exercício de 2012 marcou o primeiro ano de execução do novo modelo de PPA. O plano alterou a abrangência e mudou a estrutura dos programas e, por essas razões, concedeu nova codificação a eles, com rompimento completo em relação aos programas usados até então. A consequência prática na execução orçamentária de 2012 foi a coexistência dos programas novos com diversos programas anteriores, seja por motivo de reabertura de créditos especiais e extraordinários nos últimos quatro meses de 2011, seja em razão da execução de restos a pagar inscritos em anos anteriores" (BRASIL. Tribunal de Contas da União. Relatório e parecer prévio sobre as contas do Governo da República. Exercício 2012, p. 247). 
dificultam ao cidadão associar os custos incorridos pela administração pública aos produtos e resultados mais amplos, entregues a cada período do ciclo de gestão". ${ }^{110}$

As críticas do TCU quanto à criação dos "Programas Temáticos" encontram eco na doutrina especializada. Ronaldo Garcia considera que a adoção da referida metodologia aumentou o grau de imprecisão do PPA, argumentando que a palavra "tema” é polissêmica, não tem a especificidade desejável, e as políticas públicas são setoriais ou multissetoriais, e nunca temáticas. ${ }^{111}$ Considera também inadequada a adoção das "Iniciativas", cujo conceito adotado foi por demais abrangente, e da forma como proposta não houve clareza em diversos aspectos, faltando especificar nas ações que integram a iniciativa elementos como o peso de cada uma, a sequência na qual devem ser entregues e a respectiva distribuição espacial. ${ }^{112}$

Luiz Fernando Paulo, além de discordar da exclusão do programa como responsável pela integração entre plano e orçamento, já mencionado, considera frágeis as conceituaçõos de objetivos, metas e iniciativas, ${ }^{113}$ faltando uma relação clara das metas com o orçamento, ${ }^{114} \mathrm{e}$ a adoção de um viés político, voltado a dar o caráter mais estratégico e menos orçamentário, prejudicou o aspecto do controle, e o resultado final permite concluir ter havido um "considerável retrocesso". ${ }^{115}$

\subsubsection{O Plano Plurianual 2016-2019}

O PPA para o período de 2016 a 2019 está consubstanciado na Lei Federal n. 13.249, de 13 de janeiro de 2016, sob a denominação de "Desenvolvimento, produtividade e inclusão social", com a pretensão de direcionar a atuação do Estado para um modelo inclusivo de desenvolvimento, de forma a conciliar o crescimento econômico com a distribuição de renda e inclusão social. Propõe avançar na metodologia adotada no PPA anterior, com o fortalecimento do caráter estratégico do plano, a partir das experiências adquiridas na última versão, sem, contudo, promover alterações significativas em sua estrutura e conceitos, ${ }^{116}$ mantendo-se a orienta-

110 BRASIL. Tribunal de Contas da União. Relatório e parecer prévio sobre as contas do Governo da República. Exercício 2014, p. 55.

111 GARCIA, Ronaldo Coutinho. PPA: o que não é e o que pode ser, p. 448.

112 GARCIA, Ronaldo Coutinho. PPA: o que não é e o que pode ser, p. 450.

113 PAULO, Luiz Fernando Arantes. Plano plurianual. Teoria, prática e desafios para a sua efetividade, p. 105-106.

114 PAULO, Luiz Fernando Arantes. Plano plurianual. Teoria, prática e desafios para a sua efetividade, p. 110.

115 PAULO, Luiz Fernando Arantes. Plano plurianual. Teoria, prática e desafios para a sua efetividade, p. 113.

116 BRASIL. Ministério do Planejamento, Orçamento e Gestão. Secretaria de Planejamento e Investimentos Estratégicos. PPA 2016-2019, Desenvolvimento, produtividade e inclusão social, p. 8-10. 
ção da atuação governamental por meio de Programas Temáticos e Programas de Gestão, Manutenção e Serviços do Estado (Lei n. 13.246/2016, art. 50). Destaca como aperfeiçoamento incorporado uma maior aproximação entre a orientação estratégica e os programas temáticos. ${ }^{117}$

Tal como o anterior, há três dimensões: a Dimensão Estratégica; a Dimensão Tática; e a Dimensão Operacional.

A Dimensão Estratégica, que orienta a elaboração dos programas temáticos, é composta pela Visão de Futuro, os Eixos e as Diretrizes estratégicas. Apresenta como visão de futuro "um Brasil que se reconheça e seja reconhecido como: uma sociedade inclusiva, democrática e mais igualitária, com educação de qualidade, respeito e valorização da diversidade e que tenha superado a extrema pobreza; uma economia sólida, dinâmica e sustentável, capaz de expandir e renovar competitivamente sua estrutura produtiva com geração de empregos de qualidade e com respeito ao meio ambiente" ${ }^{118}$ A Dimensão Estratégica é prevista na forma de quatro grandes "eixos", ${ }^{119}$ que são: 1) educação de qualidade como caminho para a cidadania e o desenvolvimento social e econômico; 2) inclusão social e redução de desigualdades, com melhor distribuição das oportunidades e do acesso a bens e serviços públicos de qualidade; 3) ampliação da produtividade e da competitividade da economia, com fundamentos macroeconômicos sólidos, sustentabilidade e ênfase nos investimentos públicos e privados, especialmente em infraestrutura; e 4) fortalecimento das instituições públicas, com participação e controle social, transparência e qualidade na gestão, eixos esses desdobrados em um conjunto de diretrizes estratégicas. ${ }^{120}$

A Dimensão Tática, que compreende os Programas Temáticos, "define os caminhos exequíveis para as transformações da realidade que estão anunciadas nas Diretrizes Estratégicas, considerando as variáveis inerentes à política pública e reforçando a apropriação, pelo PPA, das principais agendas de governo e dos planos

117 BRASIL. Ministério do Planejamento, Orçamento e Gestão. Secretaria de Planejamento e Investimentos Estratégicos. Orientações para a elaboração do Plano Plurianual 2016-2019, p. 4.

118 BRASIL. Ministério do Planejamento, Orçamento e Gestão. Secretaria de Planejamento e Investimentos Estratégicos. PPA 2016-2019, Desenvolvimento, produtividade e inclusão social, Mensagem presidencial, p. 15.

119 BRASIL. Ministério do Planejamento, Orçamento e Gestão. Secretaria de Planejamento e Investimentos Estratégicos. PPA 2016-2019, Desenvolvimento, produtividade e inclusão social, Mensagem presidencial, p. 26.

120 BRASIL. Ministério do Planejamento, Orçamento e Gestão. Secretaria de Planejamento e Investimentos Estratégicos. PPA 2016-2019, Desenvolvimento, produtividade e inclusão social, Mensagem presidencial, p. 37-39. 
setoriais para os próximos quatro anos” ${ }^{121}$ Tem como novidade a explicitação da estrutura do gasto tributário federal por meio de projeções associadas aos Programas Temáticos para o período do plano. ${ }^{122}$

A Lei n. 13.249, de 2016, define como prioridades para o período do plano aquelas que constam de três planos vigentes: o Plano Nacional de Educação; o Programa de Aceleração do Crescimento (PAC); e o Plano Brasil sem Miséria (PBSM) (art. $3^{\circ}$ ); fixando oito diretrizes: I - O desenvolvimento sustentável orientado pela inclusão social; II - A melhoria contínua da qualidade dos serviços públicos; III - A garantia dos direitos humanos com redução das desigualdades sociais, regionais, étnico-raciais, geracionais e de gênero; IV - $\mathrm{O}$ estímulo e a valorização da educação, ciência, tecnologia e inovação e competitividade; V - A participação social como direito do cidadão; VI - A valorização e o respeito à diversidade cultural; VII -O aperfeiçoamento da gestão pública com foco no cidadão, na eficiência do gasto público, na transparência, e no enfrentamento à corrupção; e VIII - A garantia do equilíbrio das contas públicas.

A execução do PPA 2016-2019 foi bastante prejudicada por razões políticas, dado o conturbado período vivido pelo país, que passou pelo processo de impeachment da presidente Dilma Roussef e substituição pelo vice-presidente, que assumiu o cargo, Michel Temer, em 2016, com pouco apoio político e diversa orientação na forma de conduzir a administração pública. E é fato que o plano de governo se reflete no PPA, de modo que a alteração ocorrida invariavelmente causou prejuízos à continuidade deste. Registre-se também que a mudança de governo sem alteração no PPA indica a pouca relevância que se atribui a esse instrumento de planejamento governamental.

Mas algumas considerações podem ser feitas pela avaliação da proposta contida no plano, como já consta do documento produzido pela Consultoria Técnica do Congresso Nacional para fornecer subsídios aos deputados e senadores para apreciação do projeto de lei do Plano Plurianual.

Inicialmente, vale destacar que, já em 2014, José Celso Cardoso Júnior fez propostas para o Plano Plurianual 2016-2019, advertindo para alguns aspectos importantes, como deixar de dar primazia ao aspecto setorial sobre o territorial, esta-

121 BRASIL. Ministério do Planejamento, Orçamento e Gestão. Secretaria de Planejamento e Investimentos Estratégicos. Orientaçôes para a elaboração do Plano Plurianual 2016-2019, Mensagem presidencial, p. 5.

122 BRASIL. Ministério do Planejamento, Orçamento e Gestão. Secretaria de Planejamento e Investimentos Estratégicos. Orientaçôes para a elaboração do Plano Plurianual 2016-2019, Mensagem presidencial, p. 17. 
belecendo-se um equilíbrio entre ambas as dimensões, que se mostram cruciais para qualquer política pública ou programa de governo. ${ }^{123}$

$\mathrm{O}$ que se pode constatar é que, não obstante os esforços que se verificam no sentido de acolher a dimensão territorial na elaboração do plano, a "balança" ainda pende fortemente para a dimensão setorial, que tem presença predominante nos eixos e diretrizes que compõem a dimensão estratégica e nos programas temáticos que integram a dimensão tática, bem como nas prioridades e diretrizes explicitadas na Lei n. 13.249/2016.

Sugeriu ainda José Celso Cardoso a reforma da estrutura setorializada/departamentalizada da atuação governamental, propondo um modelo que tenha um perfil matricial, ${ }^{124}$ o que não se constatou até o momento, evidenciando ser ainda uma pretensão que está distante da realidade, não obstante se mostre efetivamente fundamental para acolher as novas demandas sociais, cujas características cada vez mais não se ajustam ao modelo de organização setorial e territorial da atual administração pública.

Críticas pertinentes são também encontradas no já citado texto do Congresso Nacional, algumas das quais merecem destaque.

A priorização do Plano Nacional de Educação, cuja versão vigente abrange todo o período do PPA, por estar vigente no período de 2014 a 2024, estabeleceu metas e estratégias que não permitem

"estabelecer correlação direta entre os indicadores utilizados, suas unidades de medida e índices adotados. Metas e iniciativas previstas no Projeto relacionam-se com metas e estratégias do PNE de forma não unívoca, que podem contribuir de forma direta ou indireta, específica ou genérica, para o cumprimento dos objetivos estabelecidos. Em várias situações, as metas previstas no PLPPA são definidas sem a adoção de um índice ou uma quantificação que deva ser atingida, o que enfraquece a vinculação do PPA com os orçamentos anuais e com o atingimento das metas previstas no PNE". ${ }^{25}$

A priorização do PAC, que não está adequadamente formalizado, exigindo uma "filtragem" de ações orçamentárias por meio do identificador de resultado primário específico, por exemplo, é um elemento que complexifica a implementação do PPA.

123 CARDOSO JR., José Celso. Política e planejamento no Brasil: balanço histórico e proposta ao Plano Plurianual 2016-2019, p. 25.

124 CARDOSO JR., José Celso. Politica e planejamento no Brasil: balanço histórico e proposta ao Plano Plurianual 2016-2019, p. 25.

125 BRASIL. Congresso Nacional - CONOF/CD - CONORF/SF. Nota técnica conjunta n. 10, de 2015. Subsídios para a apreciação do Projeto de Lei do Plano Plurianual para o período de 2016 2019 (PLN n. 06/2015-CN, encaminhado por intermédio da Mensagem n. 326/2015), p. 18. 
Problemas semelhantes verificam-se no Plano Brasil sem Miséria, a terceira prioridade, cujas intervenções governamentais por meio das quais se viabiliza não se encontram explicitados no PPA, não havendo correspondências claras e diretas nos elementos de programação orçamentária, além de ser desde já possível notar futuros problemas de restrições orçamentárias. ${ }^{126}$

Considera necessário o aperfeiçoamento do sistema de integração federativa, ainda falho, provocando a necessidade de a União assumir ações de baixo impacto estruturante e que deveriam ter participação dos entes subnacionais, que não o fazem por falta de recursos ou não estarem tecnicamente preparados. ${ }^{127}$

O documento mantém críticas já expostas por outros órgãos e especialistas, aos quais já se fez referência, no sentido de imprecisão na conceituação do que vem a ser "iniciativa", cuja definição se mostrou por demais vaga ("declarar os meios e mecanismos de gestão que viabilizam os Objetivos e explicitam o como fazer"), não ficando claro qual seu exato papel ${ }^{128}$ e o dos indicadores, observando que "não está identificada a relação de causalidade entre a execução de ações e os indicadores associados ao mesmo programa”, o que já foi destacado pelo TCU várias vezes, e também a falta de referência nos indicadores à meta esperada para o final do período. ${ }^{129}$

Outra crítica já existente permanece com o PPA 2016-2019: há um enfraquecimento como instrumento de planejamento, dada a multiplicidade de planos e programas utilizados para comunicar suas ações à sociedade, como o Programa de Aceleração do Crescimento (PAC), o Plano Brasil Sem Miséria (PBSM), o Plano de Investimento Logístico (PIL), entre outros, o que dilui e dispersa a fixação das prioridades, impedindo que o planejamento cumpra uma de suas principais funçôes.

\subsubsection{O Plano Plurianual 2020-2023130}

O plano plurianual da União, prevendo as diretrizes e metas da administração pública federal para o período 2020-2023, está materializado na Lei n. 13.971, de 27.12.2019.

126 BRASIL. Congresso Nacional - CONOF/CD - CONORF/SF. Nota técnica conjunta n. 10, de 2015, p. 19-10.

127 BRASIL. Congresso Nacional - CONOF/CD - CONORF/SF. Nota técnica conjunta n. 10, de 2015, p. 30.

128 BRASIL. Congresso Nacional - CONOF/CD - CONORF/SF. Nota técnica conjunta n. 10, de 2015, p. 31.

129 BRASIL. Congresso Nacional - CONOF/CD - CONORF/SF. Nota técnica conjunta n. 10, de 2015, p. 31.

130 Vide, sobre o tema, texto de minha autoria, em parte reproduzido: CONTI, José Mauricio. Os planos do governo Bolsonaro e a necessidade de fortalecimento do planejamento. Site Jota-Coluna Fiscal, publicado em 28.11.2019. 
Intitulado "PPA 2020-2023: planejar, priorizar, alcançar”, propõe trazer como inovações a simplificação metodológica, o realismo fiscal e o alinhamento com os planejamentos estratégicos dos ministérios e integração com a avaliação de políticas públicas. ${ }^{131}$

Pela primeira vez, foi elaborado com acompanhamento do Tribunal de Contas da União, que deu uma relevante contribuição, com observações e sugestôes úteis para o aperfeiçoamento do plano, consoante se pode constatar do Acórdão 2515/2019. Vê-se ter havido a intenção de resgatar o modelo lógico que orientou a elaboração do PPA 2000-2003, mantido até o PPA 2008-2011, mas descontinuado a partir do PPA 2012-2015. Uma medida que se evidencia correta, uma vez que o modelo anterior, introduzido no PPA 2000-3003, permitia estabelecer, na construção dos programas, uma ligação mais clara entre os problemas a serem enfrentados e as respectivas causas e consequências, sendo desenhados com objetivos expressos, açōes necessárias, metas, indicadores e resultados a serem atingidos. Não se pode constatar que no PPA 2020-2023 tenha sido integralmente acolhido o modelo anterior, especialmente ante as dificuldades na elaboração causadas pelas modificações na estrutura organizacional do setor no período. ${ }^{132}$ Mas o esforço no sentido de dotar os programas de uma coerência interna é importante e a tentativa de resgate da metodologia anterior evidencia o interesse em aperfeiçoar o plano plurianual.

O PPA 2020-2023 identifica seis grandes dimensões de ação do Estado, denominadas de "eixos": institucional, social, ambiental, econômico, de infraestrutura e estratégia de defesa, nos quais estão inseridas as políticas públicas prioritárias. Em termos financeiros, os mais bem aquinhoados são o econômico e o social (4,5 e 1,8 trilhões de reais, respectivamente, em números aproximados).

Foram estabelecidos 20 diretrizes (Lei n. 13.971, art. 30), 15 temas e 70 programas finalísticos (Anexo I), cada um com apenas um objetivo, uma meta e um indicador, mais os programas de gestão e de investimentos plurianuais, constatando-se uma redução significativa em comparação com a metodologia adotada no PPA anterior. $^{133}$ Uma simplificação com potencial de trazer mais clareza, concisão e

131 Mensagem presidencial que encaminha o Projeto de Lei do Plano Plurianual 2020-2023 e seus respectivos anexos / Ministério da Economia - Secretaria Especial de Fazenda - Secretaria de Avaliação, Planejamento, Energia e Loteria. Brasília: SECAP/Ministério da Economia, 2019, p. 4.

132 Acórdão TCU 2515/2019, Plenário, Rel. Min. Vital do Rêgo, j. 16.10.2019, p. 2 e 6.

133 Que previa 54 programas temáticos, 304 objetivos, 542 indicadores, 1.136 metas e 3.101 iniciativas (Apresentação do PPA 2020-2023. Brasília: Ministério da Economia - Secretaria da Fazenda - Secretaria de avaliação, planejamento, energia e loteria, 2019, p. 6). 
objetividade ao PPA, colaborando para que seja cumprido com fidedignidade, que é o aspecto mais importante, pois de nada adianta um minucioso detalhamento que não é observado.

Foram priorizadas as áreas da infraestrutura, defesa, segurança pública, recursos hídricos, saúde e educação infantil, como se pode constatar em alguns programas finalísticos específicos, como o "Petróleo, Gás, Derivados e Biocombustíveis" (n. 3003, com 291,5 bilhôes de reais); "Defesa nacional” (n. 6012, com 38,3 bilhões de reais); "Segurança Pública, Combate à Corrupção, ao Crime Organizado e ao Crime Violento (n. 5016, com 6,6 bilhões de reais); "Recursos hídricos" (n. 2221, com 6,5 bilhões de reais). No eixo social, que totaliza o de maior aporte financeiro, com um total de 1,7 trilhão de reais, estão programas finalísticos com recursos que ultrapassam a centena de bilhões de reais, como "Atenção primária à saúde" (n. 5019, com 203 bilhões); "Assistência farmacêutica no SUS" (n. 5017, 136 bilhões); "Atenção especializada à saúde" (n. 5018, 308 bilhôes); "Proteção Social no âmbito do sistema Único de Assistência Social - SUAS” (n. 5031, com 366 bilhões); "Inclusão Produtiva de Pessoas em Situação de Vulnerabilidade Social" (n. 5027, com 235 bilhões); "Inclusão Social por meio do Bolsa Família e da Articulação de Políticas Públicas" (n. 5028, com 120 bilhões). Na área da educação, o programa com mais recursos é "Educação básica de qualidade" (n. 5011, com 93 bilhões de reais). Mas o destaque dá-se à educação infantil, especialmente as políticas voltadas à primeira infância - 0 a 6 anos de idade, reconhecida como a prioridade do PPA 2020-2023, ${ }^{134}$ contempladas por programas como "Atenção Integral à Primeira Infância" (n. 5024, com 1,6 bilhões de reais).

Evidencia-se uma preocupação com o monitoramento e avaliação dos programas, aspecto destacado nas justificativas que apresentam o plano, e nos artigos 13 a 19 da lei, o que é importante, pois tem sido uma falha recorrente da administração pública em geral, sem solução satisfatória e pouca ênfase na busca de soluções. $\mathrm{O}$ mesmo se vê em relação à governança pública e às preocupações com articulação institucional, setorial e federativa, com a determinação de alinhamento dos demais instrumentos de planejamento, com expressa referência ao Plano Nacional de Educação e ao Plano Nacional de Políticas para as Mulheres (art. 22).

Releva destacar da mensagem presidencial encaminhadora do PPA o reconhecimento de um cenário macroeconômico de recuperação lenta da economia, que se encontra com baixo nível de crescimento, com a expectativa de retomada gradual

134 Mensagem presidencial, p. 28-29. 
e de recuperação da capacidade fiscal do Estado. A previsão de crescimento do PIB é modesta (2,2\% em 2020, atingindo 2,5\% em 2023), e a dívida pública não apresenta boas perspectivas, com resultado primário do governo central negativo até 2022, voltando a ser positivo somente em 2023 (0,20\% do PIB). Impõe como desafios para o período assegurar a sustentabilidade das finanças públicas e a estabilização da dívida pública. Para isso, além da implementação de medidas como a recém-aprovada reforma da previdência, estão entre as pretensões a reforma tributária, a continuidade do programa de concessões e privatização de empresas estatais e serviços de infraestrutura, medidas de liberalização comercial, redução e racionalização de subsídios e reforma administrativa da gestão pública.

\subsection{CONSIDERAÇÕES CRÍTICAS SOBRE O PLANEJAMENTO PLURIANUAL BRASILEIRO}

O planejamento orçamentário no Brasil tem no Plano Plurianual seu principal instrumento.

As modernas técnicas de planejamento e orçamentação indicam a necessidade de que se disponha de instrumentos que tenham as características do PPA, tal como se apresenta no ordenamento jurídico brasileiro. Deve representar um instrumento de ligação entre o planejamento do Estado por períodos de médio e longo prazos, e os orçamentos públicos que conduzirão a gestão financeira dos entes da federação. Deve também ser submetido ao Parlamento para deliberação e aprovação, com efetiva possibilidade de nele interferir, ainda que se estabeleçam algumas limitações, que devem se restringir ao mínimo possível, apenas para impedir que se atinjam áreas de atuação próprias do Poder Executivo, que possam afetar a boa gestão da atividade financeira do Estado.

O PPA brasileiro representa um avanço do ordenamento jurídico nacional em termos de planejamento normativo da atividade financeira do setor público e segue as mais modernas técnicas conhecidas para os países desenvolvidos e em desenvolvimento.

Há muitos pontos que se destacam, e evidentemente outros que precisam ser revistos e aperfeiçoados, cabendo sobre estes últimos algumas considerações críticas, que serão objeto de referência ao longo do trabalho, mas que convém expor desde já uma parte, com a finalidade de apontar algumas possíveis falhas e respectivas soluçôes.

Inicialmente, há que se fazer um ajuste nos prazos e na data de apresentação do PPA, cujo processo se inicia com a elaboração do projeto pelo Poder Executivo no primeiro ano de mandato, para ser apresentado quatro meses antes de findo o 
exercício financeiro ${ }^{135}$ e aprovado até o final da sessão legislativa. Ocorre que, como instrumento balizador da Lei de Diretrizes Orçamentárias e da Lei Orçamentária Anual, terá, no primeiro ano do mandato, aprovação em data coincidente com o da LOA, e posterior à LDO que deveria nele se basear, o que evidentemente viola toda a lógica do sistema de planejamento do qual é instrumento central. ${ }^{136}$ Há ainda a já analisada assimetria de prazos no aspecto federativo, que será mais bem analisada posteriormente (vide item 4.1), que torna relevante a coordenação entre os planos de todos os entes federados, considerando-se especialmente as políticas públicas realizadas em regime de cooperação. Com muitos recursos transferidos do ente central para os subnacionais em face das várias políticas públicas sob regime de cooperação vertical, a existência de planos plurianuais municipais em vigor, quando findo o prazo dos planos plurianuais federais e estaduais, pode gerar inconsistências jurídicas importantes, levando à insegurança no ordenamento jurídico.

Nota-se ainda a falta de um modelo, o que decorre da inexistência de legislação específica sobre este instituto. O Plano Plurianual, na forma hoje vigente, foi estabelecido pela Constituição de 1988, em seu art. 165, que o prevê como uma lei que estabeleça, "de forma regionalizada, as diretrizes, objetivos e metas da administração pública federal para as despesas de capital e outras dela decorrentes e para as relativas aos programas de duração continuada”. Inexistentes por ocasião da Lei n. 4.320, de 1964, não há como se aplicar aos planos plurianuais os dispositivos da referida legislação, que dispunha tão somente sobre os extintos "Quadro de Recursos e de Aplicação de Capital” (arts. 23 a 25). A LRF (Lei Complementar n. 101, de 2000), já sob a égide da nova Constituição, tratou do Plano Plurianual em seu art. $3^{\circ}$, que foi integralmente vetado, deixando uma lacuna legislativa no que se refere ao Plano Plurianual, que permanece até o presente momento sem norma regulamentadora, aplicando-se, no âmbito federal, apenas as que tratam das datas de apresentação, há pouco referidas.

Weder de Oliveira bem observa que

"O constituinte não soube dizer com consistência e coerência o que pretendia com o PPA. Não o queria no $\$ 1^{\circ}$ do art. 165 como um orçamento plurianual de investimento, o famoso e fracassado OPI, de que tratava a Constituição anterior, mas deu a entender

$135 \mathrm{Na}$ esfera federal, conforme legislação vigente, nos termos em que dispõe o art. $35, \$ 2^{\circ}$, I do ADCT.

136 Como já observado em texto de minha autoria: "No primeiro ano de mandato não se cumprem promessas" (2012). Consultor Jurídico. No mesmo sentido, as observações críticas de Weder de Oliveira (Curso de responsabilidade fiscal, p. 295-327). 
que todo investimento cuja execução ultrapasse um exercício financeiro deverá dele constar. No mesmo dispositivo, não o teve como instrumento de planejamento global do Estado, fixando-se em tê-lo como plano para as despesas de capital e programas de duração continuada, conceito indeterminado que, em última instância, pode significar praticamente todo o espectro da despesa governamental". ${ }^{137}$

Disso decorre uma falta de uniformidade na forma de apresentação, observando-se ao longo da evolução em cada PPA alterações que evidenciam a procura de um modelo ideal.

No Projeto de "Lei de Qualidade Fiscal" em tramitação, ${ }^{138}$ há tratamento do tema nos arts. $6^{\circ}$ a 11 . Nele, as principais novidades são a obrigatoriedade de que tenham por base o plano de governo do candidato eleito (art. $6^{\circ}$ ), um anexo de política fiscal com os objetivos de longo prazo da estratégica fiscal pelo período de dez anos e a redução do prazo de apresentação para o dia 30 de abril, sendo devolvido para sanção até o encerramento do primeiro período da sessão legislativa do primeiro ano do mandato do chefe do Poder Executivo (art. 11). Quanto à metodologia, o projeto limita-se a estabelecer que será estruturado por programas, com objetivos e indicadores (arts. $6^{\circ}$ e $7^{\circ}$, II). Não se constata, nesse ponto, avanço significativo em torno da definição mais precisa do modelo a ser adotado.

A dicotomia entre acolher um modelo de plano com caráter mais estratégico e menos orçamentário, ou vice-versa, não se mostra adequada se adotada de forma próxima a qualquer das opções. Se há, por um lado, a necessidade de tornar o plano mais estratégico, voltado a indicar prioridades, com menor especificação em termos orçamentários, dotando-o de maior flexibilidade, isso também tem levado a dificuldades nos sistemas de controle e fiscalização, bem como na implantação, como se pode constatar pelas várias críticas expostas, bem como das primeiras experiências, que não podem ser consideradas bem-sucedidas. De outro lado, a adoção de um instrumento como o PPA na forma de um "orçamento de quatro anos" enfraquece esse instrumento de planejamento orçamentário governamental, que tem a finalidade precípua de fixar as diretrizes e metas da administração pública, exigindo uma flexibilidade que não se compatibiliza com a rigidez de uma norma com as características de um orçamento detalhado das receitas e despesas. Nesse sentido, é importante destacar que um plano de médio prazo,

137 OLIVEIRA, Weder de. Curso de responsabilidade fiscal, p. 310.

138 Projeto de Lei Complementar n. 229, de 2009 - Parecer 536, de 2016 - Redação Final do Substitutivo apresentado pela Mesa Diretora em 7.6.2016. 
voltado a dirigir a Administração Pública, como é o caso do Plano Plurianual, que claramente exerce as funções de um planejamento orçamentário governamental, deve, de um lado, ser claro na escolha das prioridades, coerentes com uma estratégia nacional de longo prazo, e, de outro, dosar sua especificação e seu detalhamento, de modo a trazer informações suficientes para balizar de forma clara as previsões das respectivas leis de diretrizes orçamentárias e leis orçamentárias anuais, sem, no entanto, exagerar de modo que se identifique como um verdadeiro orçamento de quatro anos.

Nesse sentido, não se mostra na direção de uma evolução do sistema de planejamento orçamentário, o contido na PEC (Proposta de Emenda Constitucional) 188, a chamada "PEC do Pacto Federativo". Apresentada no início de novembro de 2019, parte integrante do "Plano Mais Brasil - Transformação do Estado", promove profundas alterações no sistema de planejamento orçamentário da administração pública, propondo o fim do PPA, substituindo suas funções por um "orçamento plurianual”. $\mathrm{Na}$ falta de um maior detalhamento do texto da emenda, que remete à lei complementar regulamentar essa novidade em termos de planejamento e orçamento, o que se permite concluir é que as previsões plurianuais passarão a constar anualmente da lei orçamentária, em um possível modelo de "planejamento deslizante". ${ }^{139}$ Embora facilite eventuais ajustes na correção de rumos ao longo do tempo, pode gerar insegurança jurídica, uma vez que não se tem mais a lei com vigência temporalmente definida especificando as diretrizes e metas para o período. É certo que, nos moldes atuais, o plano plurianual nunca conseguiu dar segurança jurídica, dada a falta de seriedade com que tem sido tratado desde que foi implantado pela Constituição de 1988. No entanto, como já expus, "parece mais adequado corrigir as distorções e criar a cultura do planejamento do que abandoná-lo ou mitigá-lo. E essa proposta, em uma primeira leitura, caminha no sentido de reduzir a força, importância e efetividade das normas de planejamento de médio prazo, substituindo-se-as por normas mais compatíveis com um planejamento de prazo mais curto e dotado de maior flexibilidade". ${ }^{140}$ A medida é criticada por especialistas no tema, como Luiz Fernando Arantes Paulo, que vê nela um retrocesso e uma "vitória dos interesses políticos de curto prazo sobre a profissionalização da administração e qualificação dos gastos públicos, em uma curiosa harmonização

139 O que de certa forma já está em parte contemplado com a nova redação do art. $165, \$ 14$ da Constituição, que prevê a inclusão de investimentos de natureza plurianual na lei orçamentária. 140 “O Plano Mais Brasil e o pacote de mudanças no Direito Financeiro". 
entre os governos Lula/Dilma e Bolsonaro". ${ }^{141}$ Uma proposta para ser repensada, e bem refletida pelos parlamentares ao longo da tramitação dessa PEC.

O planejamento exige clareza e deve comunicar à sociedade as prioridades do governo, e, para isso, não colabora a multiplicidade de documentos, muitos juridicamente frágeis, que prejudicam essa função, como vem ocorrendo. É necessário o fortalecimento dos instrumentos constitucionalmente previstos, com destaque, no âmbito do planejamento orçamentário, para o PPA e a LDO, evitando-se a proliferação de outros planos, de qualquer natureza, que acabam por mitigar a credibilidade desses instrumentos e prejudicar o sistema de planejamento orçamentário governamental constitucionalmente estruturado.

A plurianualidade é hoje um fato ao qual o sistema de planejamento orçamentário da administração pública brasileira deve adaptar-se, aperfeiçoando os vários mecanismos existentes e implementando outros, alguns dos quais já mencionados, a fim de que as despesas que ultrapassem o exercício financeiro possam ser contempladas e tenham a segurança jurídica que o ordenamento jurídico deve lhes proporcionar.

141 "Extinção do Plano Plurianual é retrocesso", in Folha de S. Paulo, 26.11.2019 (https://www1. folha.uol.com.br/opiniao/2019/11/extincao-do-plano-plurianual-e-retrocesso.shtml). 